\title{
Comparison of one-week versus three-week paclitaxel for advanced pan-carcinomas: systematic review and meta-analysis
}

\author{
Shitong Lin ${ }^{1,2,}{ }^{*}$, Ting Peng ${ }^{1,2, *}$, Yifan Meng ${ }^{3}$, Canhui Cao ${ }^{4}$, Peipei Gao ${ }^{1,2}$, Ping $\mathbf{W u}^{1,2}$, Wenhua Zhi ${ }^{1,2}$, \\ Ye Wei ${ }^{1,2}$, Tian Chu ${ }^{1,2}$, Binghan Liu ${ }^{1,2}$, Juncheng Wei ${ }^{1,2}$, Xiaoyuan Huang ${ }^{1,2}$, Wencheng Ding ${ }^{1,2}$, \\ Cai Cheng ${ }^{5, \&}$
}

${ }^{1}$ Cancer Biology Research Center (Key Laboratory of the Ministry of Education), Tongji Hospital, Tongji Medical College, Huazhong University of Science and Technology, Wuhan, Hubei, China

${ }^{2}$ Department of Gynecologic Oncology, Tongji Hospital, Tongji Medical College, Huazhong University of Science and Technology, Wuhan, Hubei, China

${ }^{3}$ Department of Gynecologic Oncology, State Key Laboratory of Oncology in South China, Collaborative Innovation Center for Cancer Medicine, Sun Yat-Sen University Cancer Center, Guangzhou, China

${ }^{4}$ Department of Reproductive Medicine, Peking University Shenzhen Hospital, Shenzhen, Guangdong Province, China

${ }^{5}$ Division of Cardiothoracic and Vascular Surgery, Tongji Hospital, Tongji Medical College, Huazhong University of Science and Technology, Wuhan, Hubei, China

*Equal contribution

Correspondence to: Cai Cheng; email: cai.cheng@hotmail.com

Keywords: paclitaxel, one-week, three-week, pan-carcinomas, meta-analysis

Received: September 27, 2021 Accepted: January 4, 2022

Published: February 26, 2022

Copyright: $@ 2022$ Lin et al. This is an open access article distributed under the terms of the Creative Commons Attribution License (CC BY 3.0), which permits unrestricted use, distribution, and reproduction in any medium, provided the original author and source are credited.

\section{ABSTRACT}

Paclitaxel remains the first-line chemotherapy regimen for many malignant tumors. However, prognosis and adverse events under different dosing regimens (one-week versus three-week treatment) remain contradictory in many randomized controlled trials (RCTs). Here, we performed a comprehensive meta-analysis to measure the efficacy and toxicities of these two dosing regimens. Four databases were systematically retrieved. RCTs comparing two paclitaxel dosing regimens for advanced malignant tumors with assessable outcomes (e.g., overall survival (OS), progression-free survival (PFS), toxicities, response rates) were included. In total, 19 eligible RCTs involving 9674 patients were included. Meta-analysis of pan-cancers revealed that weekly paclitaxel treatment was more beneficial regarding PFS compared to three-week paclitaxel treatment (hazard ratio $(H R)=0.90,95 \%$ confidence interval $(C I)=0.82-0.99, P=0.02)$. Nevertheless, there was no significant difference in terms of OS between the two dosing regimens $(\mathrm{HR}=0.98,95 \% \mathrm{Cl}=0.91-1.06, P=0.62)$ or other tested subgroups. In terms of serious adverse events, grade 3 or 4 (G3/4) neutropenia, G3/4 febrile neutropenia, G3/4 arthritis, and G3/4 alopecia occurred less often under weekly paclitaxel treatment. In summary, Weekly paclitaxel treatment demonstrates better PFS and fewer chemotherapy-induced hematological and non-hematological toxicities compared to the three-week paclitaxel regimen.

\section{INTRODUCTION}

Malignant tumors remain one of the major causes of shortened human life expectancy. As of 2020, it is estimated there will be 19.3 million new cancer cases and 10.0 million new cancer deaths worldwide each year [1]. Paclitaxel is a first-line chemotherapy drug commonly used to control progression of advanced 
malignancies (e.g., ovarian cancer, breast cancer, cervical cancer, endometrial cancer, and non-small cell lung carcinoma), with a standard dosing schedule of once every three weeks [2-6]. Recently, several randomized controlled trials (RCTs) have indicated that a weekly paclitaxel regimen could significantly improve patient prognosis or decrease serious adverse events [7-9]. The latest edition of the National Comprehensive Cancer Network (NCCN) guidelines also recommend weekly paclitaxel for HER2-negative breast cancer and ovarian cancer [10-12]. However, other RCTs have found no significant differences between the two paclitaxel regimens in regard to prognosis and adverse events $[13,14]$. Thus, RCT and meta-analysis outcomes are not entirely consistent, and clinicians do not have clear information as to the most appropriate paclitaxel administration schedule. Identifying the optimal paclitaxel administration schedule is critical for patient care and survival.

A meta-analysis of pan-carcinomas comparing the overall response rate (ORR) and toxicities between oneweek and three-week paclitaxel regimens was published in 2012 [15]. However, the conclusions reached in that research mistakenly suggested that weekly paclitaxel favored a better ORR due to an error in the forest plot.
Thus, in the current study, we performed a systematic meta-analysis to measure the appropriate dose and schedule regarding prognosis (e.g., overall survival (OS) and progression-free survival (PFS) and serious adverse events.

\section{RESULTS}

At the beginning of the meta-analysis, we consulted a large number of literatures and found that weekly paclitaxel may be more effective in killing tumor cells compared to 3-weeks paclitaxel [16-18]. We therefore made a schematic diagram showing the difference of different paclitaxel regimens in killing cancer cells (Figure 1A). As shown in Figure 1B, 5455 articles were identified in the four databases (Cochrane Library, PubMed, Web of Science, and Clinical Trials.gov). In total, 19 RCTs containing 9674 patients were included in our meta-analysis after excluding ineligible RCTs [79, 13, 14, 19-32].

\section{Characteristics of included RCTs}

As shown in Table 1, our meta-analysis included five ovarian cancer RCTs, six breast cancer RCTs, six nonsmall cell lung cancer RCTs, one cervical cancer
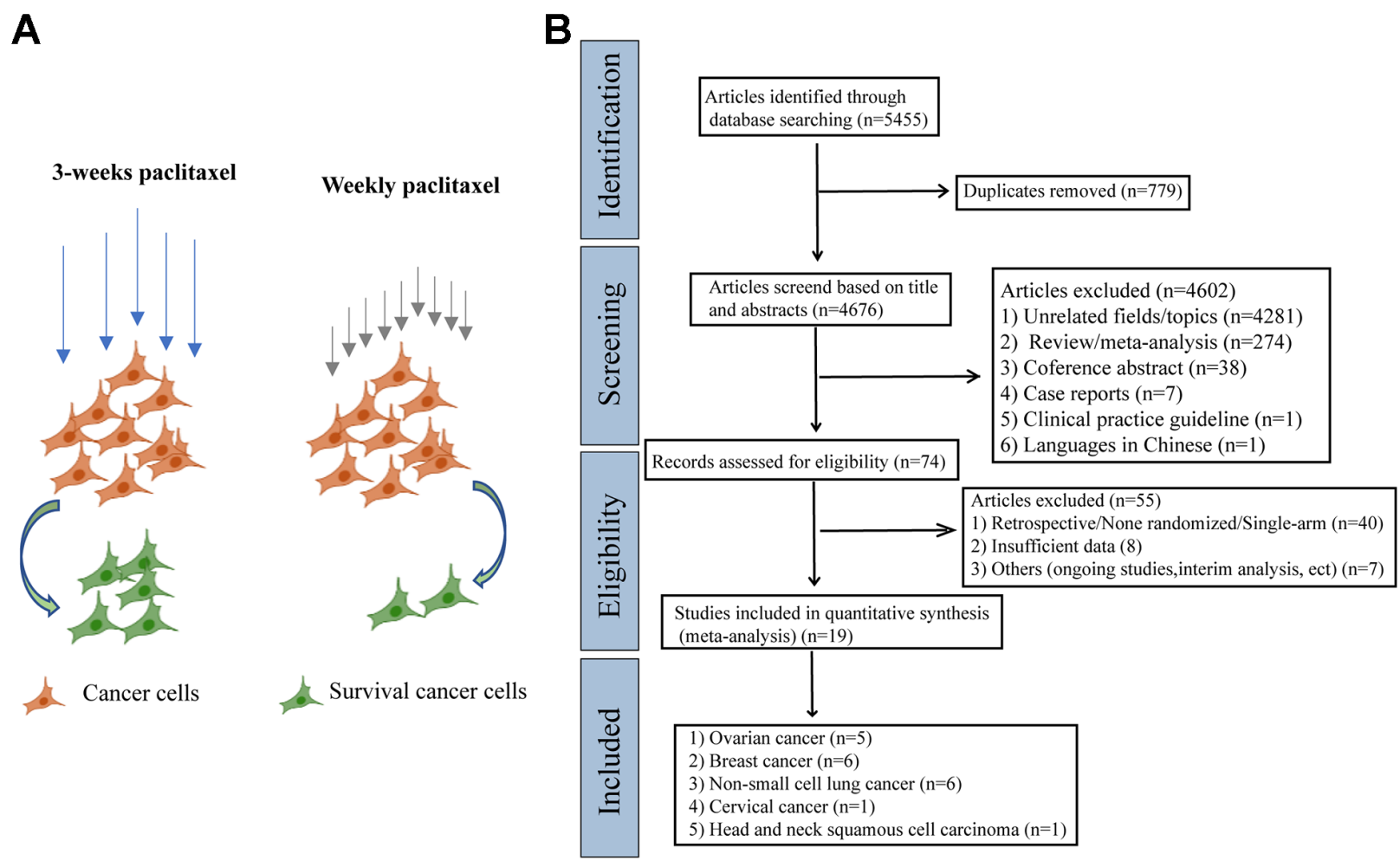

Figure 1. The schematic diagram of potential mechanism of different paclitaxel regimens and PRISMA flow diagram. (A) The schematic diagram of the effects of different paclitaxel administration schedules on the survival of cancer cells. (B) Flowchart of the literature search for the 19 eligible RCTs comparing therapeutic efficacy of weekly paclitaxel and 3-weeks paclitaxel administration schedules. 
Table 1. The characteristics of eligible clinical trials.

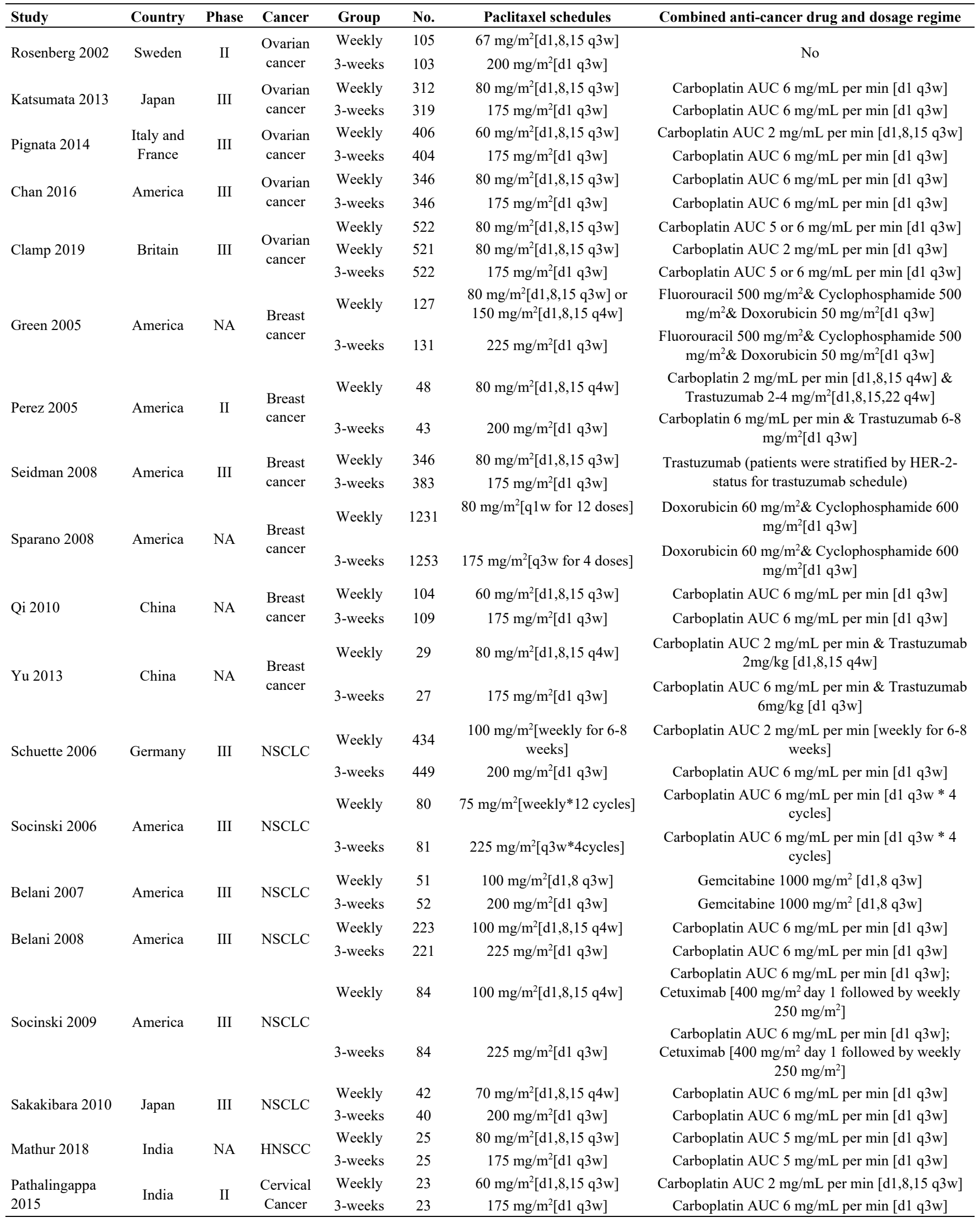

NSCLC, Non-small cell lung cancer; HNSCC, Head and neck squamous cell carcinoma; NA, not available. 
RCT, and one head and neck squamous cell carcinoma RCT. Among these RCTs, 11 were phase III RCTs, three were phase II RCTs, and five RCTs did not clearly indicate in which phase they belonged. These eligible RCTs were mainly carried out in America, India, China, and Japan, and primarily involved Asian and European races. The number of enrolled patients varied greatly among RCTs, ranging from 46 to 2484 . One cervical cancer RCT presented in the form of a conference abstract only contained data on the response rate [28]. Overall, 5059 and 4615 patients were assigned to the one-week and three-week paclitaxel regimens, respectively.

Paclitaxel and carboplatin were the main adjuvant chemotherapy drugs in the RCTs. Cetuximab, trastuzumab, doxorubicin, and cyclophosphamide were also used as combination drugs in some RCTs. There were some differences in the one-week (e.g., 60, 67, 70, $75,80,100$, and $150 \mathrm{mg} / \mathrm{m}^{2}$ ) and three-week paclitaxel regimen doses (e.g., 175, 200, and $225 \mathrm{mg} / \mathrm{m}^{2}$ ). The doses of carboplatin also varied greatly in the different RCTs. The primary outcomes of the various RCTs also differed. Ten trials displayed data efficacy (OS or PFS), toxic events, and response rates in the original manuscript, and the six non-small cell lung cancer RCTs measured all these outcomes. Two breast cancer RCTs from China by Qi et al. and $\mathrm{Yu}$ et al. only included PRR and toxicity data, respectively $[13,23]$. Furthermore, only PRR could be measured in the head and neck squamous cell carcinoma and cervical cancer RCTs.

\section{Comparative effectiveness of one-week versus three- week paclitaxel treatment weekly paclitaxel favored better PFS}

A total of 12 RCTs were included for PFS analysis. In summary, the weekly paclitaxel regimen exhibited better PFS than the three-week paclitaxel regimen (HR $=0.90,95 \% \mathrm{CI}=0.82-0.99, P=0.02)($ Figure 2). Other than paclitaxel, carboplatin was one of the main chemotherapy drugs used in the eligible RCTs under two administration schedules (area under the curve $(\mathrm{AUC})=2$ or $\mathrm{AUC}=5-6)$. According to Marchetti et al., carboplatin was defined as semi-weekly dose-dense $(\mathrm{AUC}=5-6)$ and weekly dose-dense $(\mathrm{AUC}=2)$ [33]. As shown in Figure 3, subgroup analysis revealed that semi-weekly dose-dense carboplatin favored better PFS than the three-week paclitaxel regimen $(\mathrm{HR}=0.85$, $95 \% \mathrm{CI}=0.76-0.96, P=0.008)$, but weekly dose-dense carboplatin did not show the same benefit $(\mathrm{HR}=1.02$, $95 \% \mathrm{CI}=0.89-1.17, P=0.79)$. We used the dose density ratio (DDR) to measure the significance of different doses of paclitaxel for each RCT with the formula DDR $=$ [weekly $\left.\left(\mathrm{mg} / \mathrm{m}^{2} / 3-4 \mathrm{wk}\right)\right] /[\mathrm{Q} 3$ week $\left.\left(\mathrm{mg} / \mathrm{m}^{2} / 3 \mathrm{wk}\right)\right]$ according to Huang et al. [15]. Subgroup analysis revealed that the one-week paclitaxel regimen achieved better PFS than the three-week regime in the $\mathrm{DDR}>1$ subgroup $(\mathrm{HR}=0.83,95 \% \mathrm{CI}=0.74-0.93, P=$ 0.0009). In the DDR $<1$ subgroup, however, no significant difference in PFS was found between the two paclitaxel administration schedules $(\mathrm{HR}=0.98$, $95 \% \mathrm{CI}=0.88-1.08, P=0.67$ ) (Figure 4). Further subgroup analysis based on ethnic differences revealed

\begin{tabular}{|c|c|c|c|c|c|c|c|}
\hline $\begin{array}{l}\text { PFS } \\
\text { Study or Subgroup }\end{array}$ & $\log$ [Hazard Ratio] & SE & Weight & $\begin{array}{l}\text { Hazard Ratio } \\
\text { IV, Random, 95\%CI }\end{array}$ & \multicolumn{2}{|c|}{$\begin{array}{l}\text { Hazard Ratio } \\
\text { IV, Random, 95\%CI }\end{array}$} & \\
\hline Rosenberg 2002 & 0.0488 & 0.1717 & $5.2 \%$ & $1.05[0.75,1.47]$ & \multirow{2}{*}{\multicolumn{2}{|c|}{ 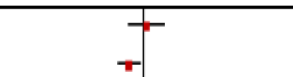 }} & \\
\hline Katsumata 2013 & -0.2744 & 0.1039 & $9.5 \%$ & $0.76[0.62,0.93]$ & & & \\
\hline Pignata 2014 & -0.0408 & 0.093 & $10.5 \%$ & $0.96[0.80,1.15]$ & \multicolumn{2}{|c|}{+} & \\
\hline Chan 2016 & -0.1165 & 0.0942 & $10.4 \%$ & $0.89[0.74,1.07]$ & & \\
\hline Clamp 2019 & -0.0943 & 0.0594 & $13.9 \%$ & $0.91[0.81,1.02]$ & \multirow{2}{*}{\multicolumn{2}{|c|}{$=$}} & \\
\hline Perez 2005 & -0.4463 & 0.4403 & $1.1 \%$ & $0.64[0.27,1.52]$ & \multirow{3}{*}{\multicolumn{2}{|c|}{$\boldsymbol{\tau}$}} & \\
\hline Seidman 2008 & -0.3011 & 0.0821 & $11.5 \%$ & $0.74[0.63,0.87]$ & & & \\
\hline Schuette 2006 & 0.1398 & 0.0713 & $12.6 \%$ & $1.15[1.00,1.32]$ & & & \\
\hline Belani 2007 & -0.3425 & 0.2105 & $3.9 \%$ & $0.71[0.47,1.07]$ & \multicolumn{2}{|c|}{$\rightarrow$} & \\
\hline Belani 2008 & -0.0408 & 0.093 & $10.5 \%$ & $0.96[0.80,1.15]$ & \multicolumn{2}{|c|}{$t$} & \\
\hline Socinski 2009 & -0.1054 & 0.143 & $6.7 \%$ & $0.90[0.68,1.19]$ & \multicolumn{2}{|c|}{$\rightarrow$} & \\
\hline Sakakibara 2010 & -0.1744 & 0.1978 & $4.3 \%$ & $0.84[0.57,1.24]$ & \multicolumn{2}{|c|}{+} & \\
\hline Total $(95 \%$ CI) & & & $100 \%$ & $0.90[0.82,0.99]$ & \multicolumn{2}{|r|}{1} & \\
\hline \multicolumn{4}{|c|}{$\begin{array}{l}\text { Heterogeneity: } \mathrm{Chi}^{\wedge} 2=23.73, \mathrm{df}=11(\mathrm{P}=0.01) ; \mathrm{I}^{\wedge} 2=54 \% \\
\text { Test for overall effect: } \mathrm{Z}=2.28(\mathrm{P}=0.02)\end{array}$} & 0.01 & \multicolumn{3}{|c|}{$\begin{array}{ccc}1 & 10 & 100 \\
& \text { Favours [3-weeks] }\end{array}$} \\
\hline
\end{tabular}

Figure 2. The forest plot of HR for PFS in the weekly paclitaxel compared to 3-weeks paclitaxel regimen. HR: hazard ratio; PFS: progression-free survival. 
PFS

Hazard Ratio Hazard Ratio

Study or Subgroup log [Hazard Ratio] $\quad$ SE $\quad$ Weight $\quad$ IV, Random, 95\%CI $\quad$ IV, Random, 95\%CI

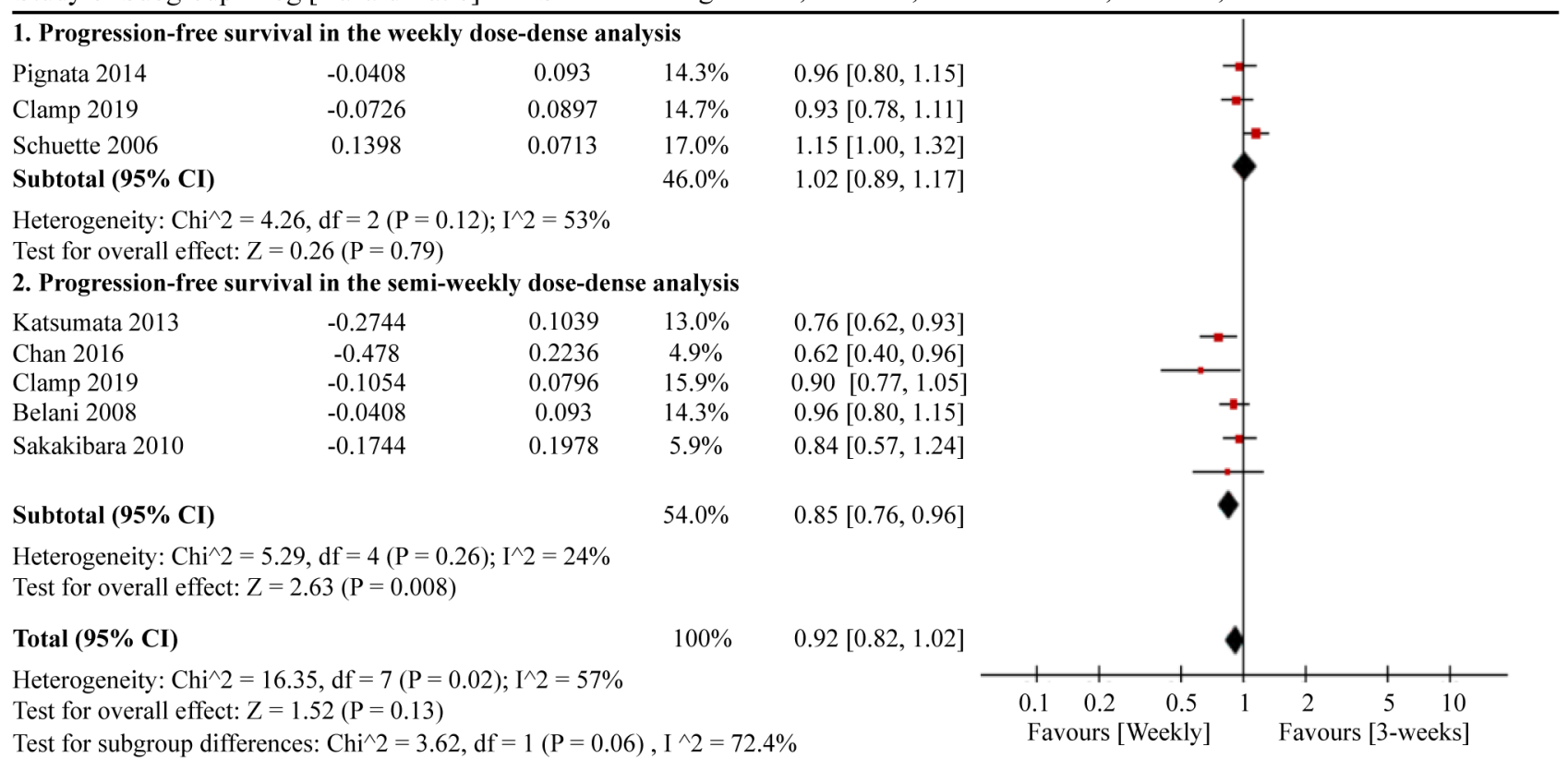

Figure 3. The forest plot of HR for PFS in the subgroup analysis based on carboplatin administration schedules. HR: hazard ratio; PFS: progression-free survival.

PFS

Study or Subgroup $\log$ [Hazard Ratio] $\quad$ SE

1. Progression-free survival in the DDR $>1$ group

Katsumata 2013

Chan 2016

Seidman 2008

Clamp 2019

Total $(\mathbf{9 5} \% \mathrm{CI})$$$
-0.2744
$$

$-0.1165$

$-0.3011$

$-0.0943$

Heterogeneity: $\mathrm{Chi}^{\wedge} 2=5.50, \mathrm{df}=3(\mathrm{P}=0.14) ; \mathrm{I}^{\wedge} 2=45 \%$

Test for overall effect: $Z=3.32(P=0.0009)$

\section{Progression-free survival in the $\mathrm{DDR}<=1$ group}

Rosenberg 2002

Pignata 2014

Perez 2005

Schuette 2006

Belani 2007

Belani 2008

Socinski 2009

Sakakibara 2010

0.0488

$-0.0408$

$-0.4463$

0.1398

$-0.3425$

$-0.0408$

$-0.1054$

$-0.1744$

Subtotal (95\% CI)

Heterogeneity: $\mathrm{Chi}^{\wedge} 2=9.31, \mathrm{df}=7(\mathrm{P}=0.23) ; \mathrm{I}^{\wedge} 2=25 \%$

Test for overall effect: $\mathrm{Z}=0.43(\mathrm{P}=0.67)$

\section{Total (95\% CI)}

Heterogeneity: $\mathrm{Chi}^{\wedge} 2=23.73, \mathrm{df}=11(\mathrm{P}=0.01) ; \mathrm{I}^{\wedge} 2=54 \%$

Test for overall effect: $\mathrm{Z}=2.28(\mathrm{P}=0.02)$

Test for subgroup differences: $\mathrm{Chi}^{\wedge} 2=4.47, \mathrm{df}=1(\mathrm{P}=0.03), \mathrm{I}^{\wedge} 2=77.6 \%$
Hazard Ratio Hazard Ratio

Weight IV, Random, $95 \% \mathrm{CI} \quad$ IV, Random, $95 \% \mathrm{CI}$
$0.76[0.62,0.93]$

$0.89[0.74,1.07]$

$0.74[0.63,0.87]$

$0.91[0.81,1.02]$

$0.83[0.74,0.93]$

$\begin{array}{ccl}0.1717 & 5.2 \% & 1.05[0.75,1.47] \\ 0.093 & 10.5 \% & 0.96[0.801 .15] \\ 0.4403 & 1.1 \% & 0.64[0.27,1.52] \\ 0.0713 & 12.6 \% & 1.15[1.00,1.32] \\ 0.2105 & 3.9 \% & 0.71[0.47,1.07] \\ 0.093 & 10.5 \% & 0.96[0.80,1.15] \\ 0.143 & 6.7 \% & 0.90[0.68,1.19] \\ 0.1978 & 4.3 \% & 0.84[0.57,1.24] \\ & 54.7 \% & 0.98[0.88,1.08]\end{array}$

$100.0 \% \quad 0.90[0.82,0.99]$

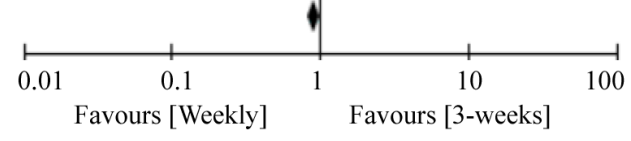

Figure 4. The forest plot of HR for PFS in the subgroup analysis based on the DDR of paclitaxel. HR: hazard ratio; PFS: progression-free survival; DDR: dose density ratio. 
that weekly paclitaxel regimen could improve patients' PFS compared to 3-weeks paclitaxel regimen in North American $(\mathrm{HR}=0.84,95 \% \mathrm{CI}=0.76-0.94, P=0.002)$ and Asia ( $\mathrm{HR}=0.78,95 \% \mathrm{CI}=0.65-0.93, P=0.006)$, but not in Europe $(\mathrm{HR}=1.01,95 \% \mathrm{CI}=0.89-1.14, P=$ 0.93 ) (Figure 5).

\section{One-week paclitaxel treatment did not obtain OS benefit compared to three-week paclitaxel treatment}

In total, 13 eligible RCTs were included for OS analysis. In general, no significant difference in OS was found between the two paclitaxel regimens $(\mathrm{HR}=0.98,95 \% \mathrm{CI}=0.91-1.06, \quad P=0.62)$ (Supplementary Figure 1). Subgroup analyses were also performed. As shown in Supplementary Figures 2, 3 , no significant differences in OS in the subgroups of the two paclitaxel schedules were detected: i.e., weekly dose-dense $(\mathrm{HR}=1.07,95 \% \mathrm{CI}=0.94-1.21, P$ $=0.32)$, semi-weekly dose-dense $(\mathrm{HR}=0.92,95 \% \mathrm{CI}=$ $0.78-1.08, P=0.31)$, DDR $>1$ group $(\mathrm{HR}=0.93$, $95 \% \mathrm{CI}=0.73-1.17, P=0.51)$, and DDR $<1(\mathrm{HR}=$ $1.05,95 \% \mathrm{CI}=0.95-1.15, P=0.33)$. There were no obvious differences between weekly and 3-weeks paclitaxel regimens regarding OS in North American $(\mathrm{HR}=0.97,95 \% \mathrm{CI}=0.81-1.15, P=0.69)$, Europe $(\mathrm{HR}=1.08,95 \% \mathrm{CI}=0.95-1.21, P=0.24)$, and Asia $(\mathrm{HR}=0.88,95 \% \mathrm{CI}=0.61-1.29, \quad P=0.52)$ (Supplementary Figure 4).

\section{Three-week paclitaxel favored better ORR}

Response rate is an important indicator for measuring the efficacy of chemotherapy drugs. In this metaanalysis, we determined the ORR, complete response rate (CRR), and partial response rate (PRR) of the two paclitaxel dosing regimens. As shown in Figure 6, 1367 ORR events occurred in 13 RCTs containing 3464 patients. Interestingly, the three-week paclitaxel regimen favored a better ORR than the weekly paclitaxel regimen (odds ratio $(\mathrm{OR})=1.29,95 \% \mathrm{CI}=$ $1.12-1.48, P=0.0005)$. No obvious differences in CRR $(\mathrm{OR}=1.04,95 \% \mathrm{CI}=0.71-1.53, P=0.83)$ or $\mathrm{PRR}(\mathrm{OR}$ $=0.96,95 \% \mathrm{CI}=0.76-1.22, P=0.75)$ were observed between the one-week and three-week paclitaxel regimens.

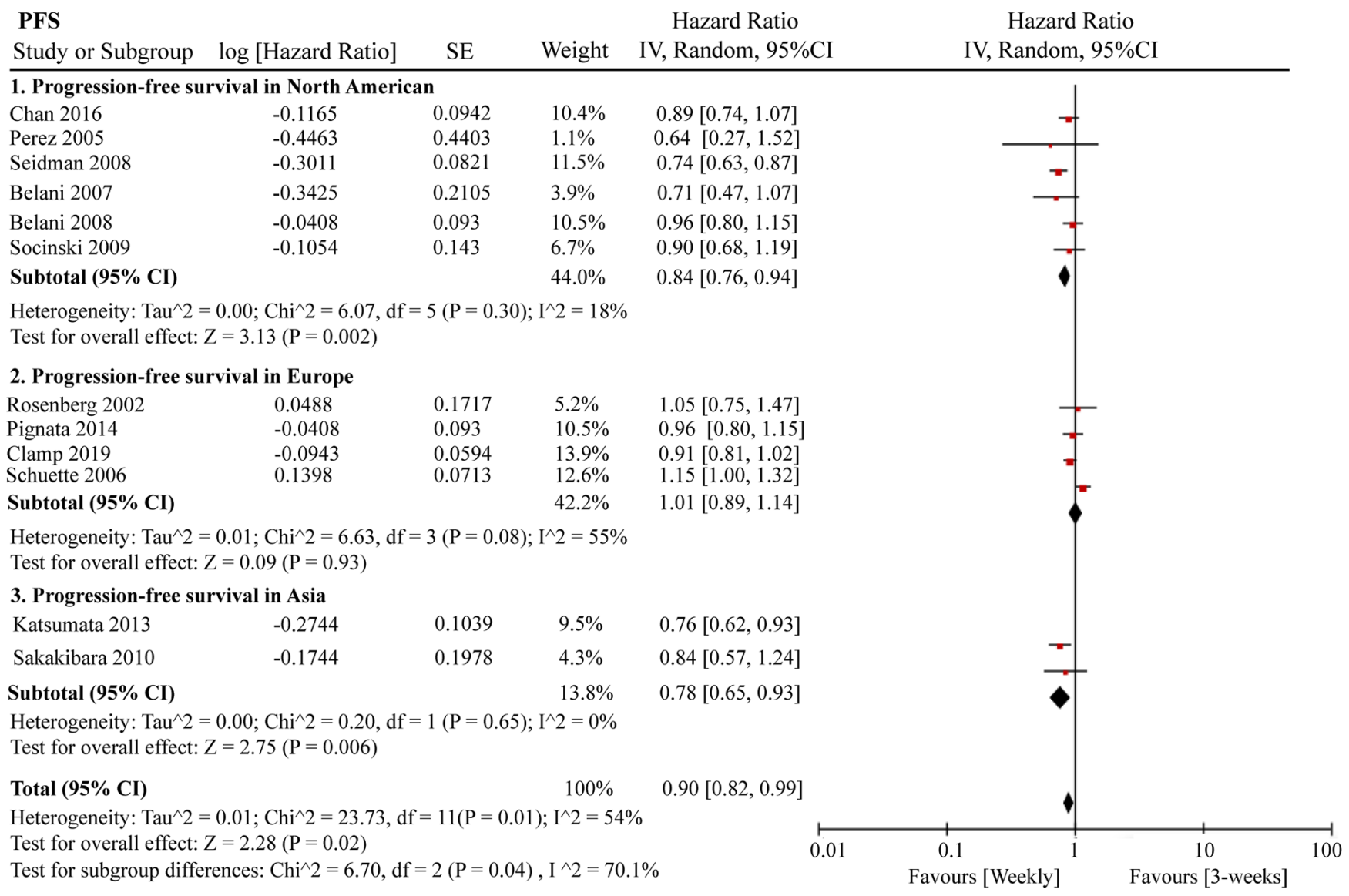

Figure 5. The forest plot of HR for PFS in the subgroup analysis based on the ethnic differences. HR: hazard ratio; PFS: progression-free survival. 


\section{G3/4 adverse events in one-week and three-week paclitaxel treatment}

We included G3/4 hematological and nonhematological toxicities in this RCT meta-analysis.
Globally, serious adverse events were less likely to occur in the weekly paclitaxel regimen. As shown in Figure 7, chemotherapy-induced G3/4 neutropenia $(\mathrm{OR}=0.60,95 \% \mathrm{CI}=0.40-0.89, P=0.01)$ and $\mathrm{G} 3 / 4$ febrile neutropenia $(\mathrm{OR}=0.67,95 \% \mathrm{CI}=0.47-0.97$,

ORR

Weekly

3-weeks

Odds Ratio

Odds Ratio

Study or Subgroup Events Total

Events Total Weight

$\mathrm{M}-\mathrm{H}$, Fixed, 95\%CI

M-H, Fixed, 95\%CI

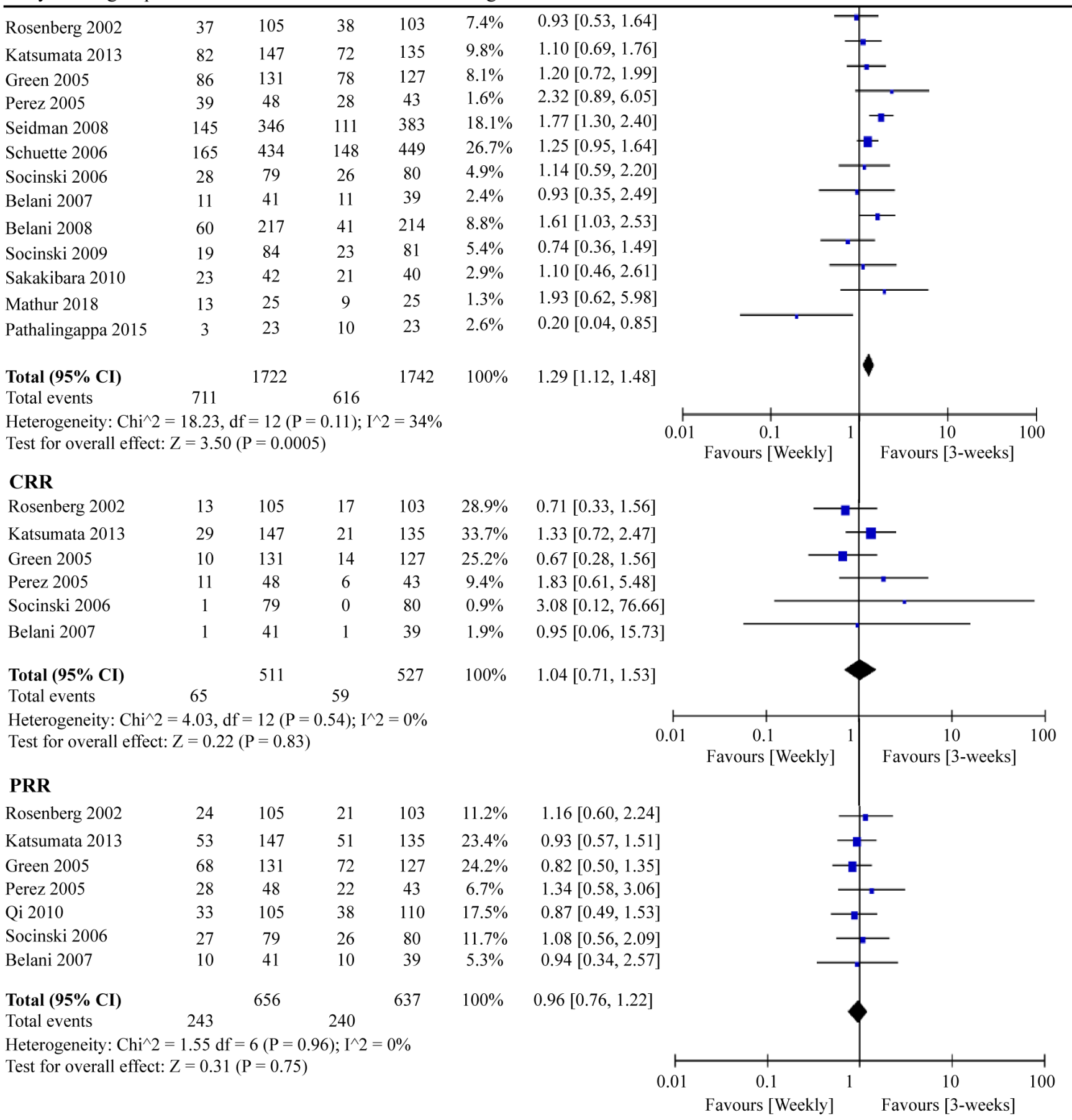

Figure 6. The forest plot of OR for ORR, CRR, and PRR in the weekly paclitaxel compared to 3-weeks paclitaxel regimen, respectively. OR: odds ratio; ORR: overall response rate; CRR: complete response rate; PRR: partial response rate. 


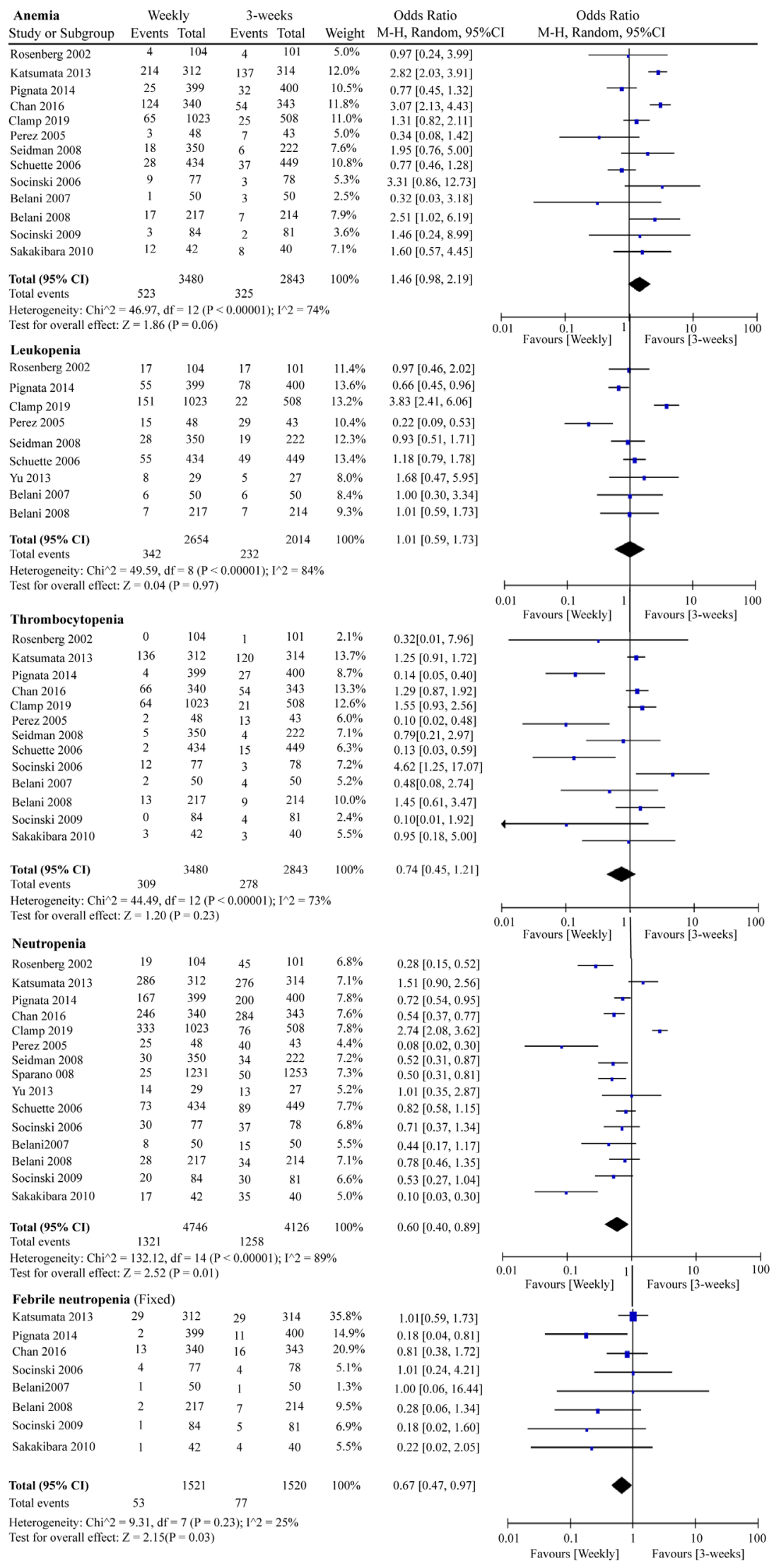

Figure 7. The forest plot of OR for hematologic toxicities (anemia, leukopenia, thrombocytopenia, neutropenia, and febrile neutropenia) in the weekly paclitaxel compared to 3-weeks paclitaxel regimen. OR: odds ratio. 
$P=0.03)$ occurred less frequently under weekly paclitaxel treatment. Nevertheless, there were no significant differences in the incidences of $\mathrm{G} 3 / 4$ anemia $(\mathrm{OR}=1.46,95 \% \mathrm{CI}=0.98-2.19, P=0.06)$, leukopenia $(\mathrm{OR}=1.01,95 \% \mathrm{CI}=0.59-1.73, P=0.97)$, or thrombocytopenia $(\mathrm{OR}=0.74,95 \% \mathrm{CI}=0.45-1.21$, $P=0.23$ ) between the two different paclitaxel schedules. In terms of non-hematological adverse events, weekly paclitaxel showed a lower frequency of $\mathrm{G} 3 / 4$ arthritis $(\mathrm{OR}=0.34,95 \% \mathrm{CI}=0.17-0.66, P=$ $0.001)$ and $\mathrm{G} 3 / 4$ alopecia $(\mathrm{OR}=0.31,95 \% \mathrm{CI}=0.19$ $0.49, P<0.00001)$ compared to the three-week paclitaxel regimen, but a higher occurrence of G3/4 diarrhea $(\mathrm{OR}=1.65,95 \% \mathrm{CI}=1.18-2.30, P=0.003)$. No obvious differences in the occurrence of G3/4 vomiting $(\mathrm{OR}=0.87,95 \% \mathrm{CI}=0.61-1.23, P=0.43)$, nausea $(\mathrm{OR}=1.04,95 \% \mathrm{CI}=0.77-1.39, P=0.81)$, infection $(\mathrm{OR}=1.11,95 \% \mathrm{CI}=0.71-1.75, P=0.64)$, fatigue $(\mathrm{OR}=1.1695 \% \mathrm{CI}=0.85-1.56, P=0.35)$, dyspnea $(\mathrm{OR}=1.14,95 \% \mathrm{CI}=0.72-1.79, P=0.57)$, constipation $(\mathrm{OR}=0.78,95 \% \mathrm{CI}=0.44-1.39, P=$ $0.40)$, or neuropathy $(\mathrm{OR}=0.90,95 \% \mathrm{CI}=0.54-1.50$, $P=0.68)$ were detected between the two paclitaxel administration schedules (Supplementary Figure 5).

\section{Quality assessment and publication bias analysis of RCTs}

Quality assessment of the 19 RCTs is shown in Figure 8 according to the Cochrane Collaboration risk of bias tool. The overall risk of the included RCTs was moderate. Undetermined risk was mainly due to a lack of relevant information. The funnel plot cannot really measure the publication bias of the included studies when the included studies were less than 10 [34]. Therefore, we only measured the publication bias of the included RCTs regarding OS, PFS, and ORR using the funnel plot. As shown in Supplementary Figure 6, publication biases regarding OS and ORR were not identified, but evident publication bias was found for PFS. Thus, we used the trim and fill method to correct for this bias $[35,36]$. As seen in Supplementary Figure 7, blank1 $(\mathrm{HR}=1.39,95 \% \mathrm{CI}=0.59-3.29)$ and blank2 $(\mathrm{HR}=1.00,95 \% \mathrm{CI}=0.87-1.15)$ were used to correct the publication bias, and the adjusted pooled HR (HR = $0.93,95 \% \mathrm{CI}=0.88-0.98, P=0.004)$ for PFS still showed a significant difference.

\section{DISCUSSION}

Paclitaxel is the cornerstone of first-line chemotherapy due to its significant anti-angiogenic effects. Both oneweek and three-week paclitaxel administration are used as standard chemotherapy regimens for certain malignancies $[16,37,38]$. Weekly paclitaxel administration has a reliable theoretical basis and several preclinical models have proven that continuous low-dose paclitaxel administration has obvious antiangiogenesis and pro-cell apoptosis effects [39]. In addition, several clinical trials have also indicated that a weekly paclitaxel regimen could provide more stable and greater dose intensity in the plasma, thereby enhancing paclitaxel exposure and intra-tumoral drug perfusion [40-43]. Therefore, it is difficult for tumor cells to recover quickly from paclitaxel-induced damage, resulting in a reduction of invasive or proliferative abilities [33, 44]. Here, we performed a systematic meta-analysis to compare the efficacies and toxicities of two paclitaxel administration schedules on pan-cancers. In total, 19 eligible RCTs containing 9674 patients were included. Results revealed that, compared to the three-week paclitaxel administration schedule, weekly paclitaxel significantly prolonged PFS and demonstrated a lower incidence of serious adverse events in advanced malignant tumors.

Several included RCTs showed results consistent with our conclusions, confirming that weekly paclitaxel can significantly improve patients' prognosis $[7,9,25]$ and is better tolerated by patients $[9,19,30]$. For example, Katsumata et al. concluded that dose-dense weekly paclitaxel can significantly improve OS and PFS in advanced ovarian cancer patients [7]. Furthermore, Belani et al. indicated that weekly paclitaxel plus carboplatin or gemcitabine can decrease toxic events [9, 30]. However, Socinski et al. reported that ORR and survival outcomes are similar between the two paclitaxel administration schedules [31]. Clamp et al. also revealed that weekly paclitaxel regimen not only does not improve patient PFS, but also causes more G3/4 toxic events than that under the standard regimen [14]. In addition, other meta-analyses comparing the efficacy of paclitaxel administration schedules on ovarian, breast, and non-small cell lung cancers report inconsistent conclusions [33, 45, 46]. For example, Marchetti et al. concluded that the three-week paclitaxel regimen should remain as the standard therapy for ovarian cancer [33], whereas Mauri et al. suggested that weekly paclitaxel should be used for advanced/metastatic breast cancer due to OS advantages [46]. Based on these contradictions, we performed a meta-analysis to incorporate the latest high-quality RCTs to measure differences between the two paclitaxel regimens.

The doses of paclitaxel received by patients under the weekly or three-week paclitaxel regimens were not consistent. As such, DDR was used to balance the impact of paclitaxel dose differences on outcome evaluation. Results showed that weekly paclitaxel administration demonstrated better PFS than the threeweek paclitaxel regime when DDR $>1$. The carboplatin administration schedules also varied in the weekly 
A

\begin{tabular}{|c|c|c|c|c|c|c|c|c|}
\hline $\begin{array}{l}\text { + Low risk } \\
\text { ? Unclear } \mathrm{r} \\
\text { - High risk }\end{array}$ & & 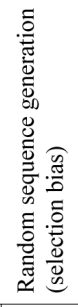 & 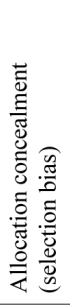 & 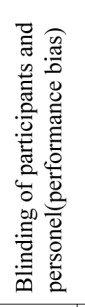 & 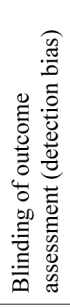 & 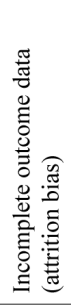 & 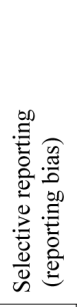 & 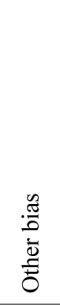 \\
\hline Rosenberg 2002 & & + & + & $?$ & $?$ & + & + & + \\
\hline Clamp 2019 & & + & + & + & + & $?$ & + & + \\
\hline Pignata 2014 & ov & + & + & + & + & + & + & + \\
\hline Katsumata 2013 & & + & + & + & $?$ & + & + & + \\
\hline Chan 2016 & & + & $?$ & $?$ & + & + & + & $?$ \\
\hline Pathalingappa 2015 & CESC & + & $?$ & $?$ & $?$ & + & + & $?$ \\
\hline Mathur 2018 & HNSC & + & $?$ & $?$ & $?$ & $?$ & $\oplus$ & $?$ \\
\hline Socinski 2006 & \multirow{6}{*}{$\begin{array}{c}\text { NSCL } \\
\text { C }\end{array}$} & $\odot$ & $?$ & $?$ & $?$ & + & + & $\oplus$ \\
\hline Schuette 2006 & & + & $?$ & $?$ & + & + & + & + \\
\hline Belani 2007 & & + & $?$ & $?$ & $?$ & + & + & $\oplus$ \\
\hline Belani 2008 & & + & $?$ & $?$ & $?$ & $\oplus$ & $\oplus$ & $\oplus$ \\
\hline Socinski 2009 & & + & $?$ & $?$ & $?$ & - & $\oplus$ & $?$ \\
\hline Sakakibara 2010 & & + & $?$ & $?$ & $?$ & $\oplus$ & + & - \\
\hline Yu 2013 & \multirow{6}{*}{ BRCA } & + & + & $?$ & $?$ & + & + & - \\
\hline Green 2005 & & + & $?$ & $?$ & $?$ & $\oplus$ & + & $?$ \\
\hline Perez 2005 & & + & + & $?$ & $?$ & + & + & - \\
\hline Seidman 2008 & & - & $?$ & $?$ & $?$ & + & + & + \\
\hline Sparano 2008 & & + & + & + & + & + & + & + \\
\hline Qi 2010 & & + & $?$ & $?$ & $?$ & + & - & + \\
\hline
\end{tabular}

B

Random sequence generation (selection bias)

Allocation concealment (selection bias)

Blinding of participants and personel(performance bias)

Blinding of outcome assessment (detection bias)

Incomplete outcome data (attrition bias)

Selective reporting (reporting bias)

Other bias

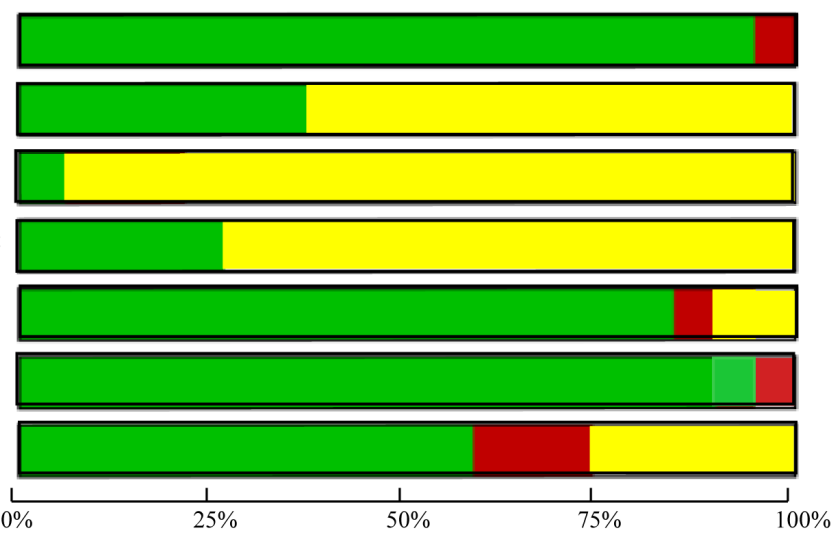

Low risk

Unclear risk

High risk

Figure 8. Quality assessments of the included RCTs. (A) Risk of bias summary. (B) Risk of bias graph. 
paclitaxel regimen. Subgroup analysis revealed that the semi-weekly regimen (i.e., carboplatin (AUC $=5-6)+$ weekly paclitaxel) favored better PFS. Thus, we hypothesized that within a certain drug-dose range, there was a positive correlation between patient prognosis and paclitaxel/carboplatin dose. However, the appropriate concentration range for paclitaxel and carboplatin needs further study. Ethic differences are also important factors affecting the efficacy of paclitaxel. Studies have shown that the expression level of CYP450 enzyme varied greatly in different ethnic populations, which was reported to play major roles in paclitaxel metabolism $[47,48]$. Here, we also found that weekly paclitaxel regimen could improve patients' PFS compared to 3-weeks paclitaxel regimen in North American and Asia, but not in Europe.

Our meta-analysis exhibits several specific strengths. While Huang et al. performed a similar meta-analysis on 10 RCTs in 2012 [15], only differences in G3 sensory neuropathy, G3/4 neutropenia, and response rate between one-week and three-week paclitaxel regimens were examined, and they mistakenly concluded that the weekly regimen favored a better response rate. Actually, we re-performed meta-analysis on these data, and concluded that 3 -weeks regimen favored a better response rate $(\mathrm{OR}=1.24,95 \% \mathrm{CI}=1.01-1.52, P=0.04)$ (Supplementary Figure 8). Here, we were the first metaanalysis to compare the differences of efficacy and toxicities between weekly and 3-weeks paclitaxel regimens on pan-carcinomas in last decade, which included 19 eligible RCTs and 9674 patients. Here, we comprehensively analyzed the differences in prognosis (OS and PFS), response rate, and G3/4 toxicities between the two administration schedules. At the pancancer level, we found that weekly paclitaxel favored better PFS with a lower risk of G3/4 adverse events, whereas the three-week paclitaxel regimen favored better ORR, with CRR and PRR found to be similar between the groups. The higher ORR but poorer PFS in three-week regimen did not appear contradictory, which could be explained by differences in individual patient characteristics (e.g., age, sex), body status, drug resistance, and serious complications. Patient's tolerance and response rate to paclitaxel need to be fully considered at the same time. Although 3-weeks paclitaxel obtained a higher response rate, it was accompanied by a higher rate of adverse events. G3/4 neutropenia and febrile neutropenia are life-threatening toxicities, and G3/4 arthritis and alopecia also seriously affect the quality of patients' life. Actually, higher response rate to chemotherapy but no better prognosis has been proven in other cancers $[49,50]$.

This research should provide good guidance for clinicians and health policy makers. When selecting the most appropriate paclitaxel administration schedule, the efficiency, cost, toxicity, and treatment delays induced by adverse events should be seriously considered. The current meta-analysis revealed that the weekly paclitaxel regimen can significantly prolong PFS and decrease the incidence of adverse events. We realize the change in paclitaxel administration from three weeks to one week is a challenge for gynecological oncology due to the increase in the number of admissions and drug administration [21]. Cost-effectiveness is an important factor influencing treatment decisions. Chan et al. showed that the incremental cost-effectiveness ratio was $\$ 5809$ per progression-free life-year saved for weekly paclitaxel compared with three-week paclitaxel, and the weekly paclitaxel regimen was a cost-effective treatment option for advanced ovarian cancer using a Markov decision model [51]. Several studies have explored the economic benefits of paclitaxel in the treatment of advanced or metastatic breast cancer, but did not compare the differences between the two administration schedules $[52,53]$. Prospective RCTs should clarify this in other malignant tumors in future studies.

Our meta-analysis has several limitations. Firstly, baseline characteristics of the enrolled patients varied among the RCTs, e.g., age, ECOG performance status, and clinical stage, which may affect outcome assessment. For example, elderly patients or those in poor physical condition tended to have poorer tolerance to chemotherapy drugs, thus leading to more adverse events and treatment delays. Secondly, a publication bias regarding PFS was found. Although this bias was corrected by the trim and fill method, the heterogeneity $\left(\mathrm{I}^{\wedge}\right)$ of the included studies (RCTs plus two blanks) was $50 \%$, which is the cut-off value. Therefore, we should be cautious when measuring PFS. Finally, some HRs for OS and PFS were not presented in the original manuscripts (Rosenberg 2002, Schuette 2006, and Perez 2005) $[19,26,32]$, and were instead obtained from the survival curve.

In summary, compared to the three-week paclitaxel administration schedule, weekly paclitaxel treatment showed a PFS advantage and lower risk of complications. Thus, a weekly paclitaxel regimen is recommended as a first-line chemotherapy for advanced malignant tumors, especially for elderly patients in poor physical condition.

\section{MATERIALS AND METHODS}

\section{Literature retrieval strategy}

Our meta-analysis was carried out under the guidance of the PRISMA Statement [54]. To identify all relevant RCTs, we systematically searched four databases, 
including Cochrane Library, PubMed, Web of Science, and Clinical Trials.gov, from study inception to December 2020. The Medical Subject Heading (MESH) terms included "paclitaxel", "weekly", "dose-dense", and "randomized". Only RCTs were included in our study. Previous meta-analyses and systematic reviews were used for reference in detailed search strategies for each database $[15,33,45,46,55]$. Details on the literature retrieval strategy are described in Supplementary Table 1 . We have registered this metaanalysis in PROSPERO, and the granted number is CRD42020213815.

\section{Eligible study selection}

Those RCTs that compared the efficacy and/or adverse events of one-week and/or three-week paclitaxel regimens were considered eligible. In addition to paclitaxel, carboplatin and other adjuvant chemotherapy drugs were also included in the two different paclitaxel administration groups. RCTs were excluded if they were not written in English, showed a small sample size $(\mathrm{n}<10)$, or showed no measurable outcomes.

\section{Data extraction and quality assessment}

We focused on the reported OS, PFS, ORR, CRR, PRR, and G3/4 adverse events. Details on the included studies were extracted, including first author's name, country, starting time of trial, number of patients, patient characteristics, and interventions (detailed drug administration schedules). We performed quality assessment of the included RCTs according to the Cochrane Collaboration risk of bias tool [56]. Seven bias risks were included: i.e., random sequence generation, allocation concealment, blinding of participants and personnel, blinding of outcome assessment, incomplete outcome data, selective reporting, and others. The relevant research work was performed independently by two reviewers (Ting Peng and Shitong Lin). Divergences in opinion were resolved through discussion and consensus between the two reviewers or by discussion with Professor Cai Cheng.

\section{Outcome and subgroup analysis}

Data outcomes were extracted from the published articles with the longest follow-up. Primary outcomes were OS and PFS. Secondary outcomes included ORR, PRR, CRR, and G3/4 hematological and nonhematological toxicities.

We performed subgroup analysis to further measure the effects of different paclitaxel administration schedules. Firstly, the doses of paclitaxel received by patients in each treatment cycle for the two different administration schedules were not the same. We used the DDR to measure the effects of dose differences on outcome assessment. Here, DDR ([weekly $\left.\left.\left(\mathrm{mg} / \mathrm{m}^{2}\right) \times 3 / 3-4 w k\right)\right]$ / [3 weeks $\left.\left.\left(\mathrm{mg} / \mathrm{m}^{2}\right) / 3-4 \mathrm{wk}\right)\right]$ ) refers to the ratio of the weekly paclitaxel dose received by patients under the two paclitaxel administration regimens over each course of treatment [15]. Secondly, paclitaxel plus carboplatin was the main chemotherapy regimen, and carboplatin was used under two different administration schedules $(\mathrm{AUC}=2$ or $\mathrm{AUC}=5-6)$ [33]. Thus, we used the DDR and carboplatin administration schedules to perform subgroup analysis. Finally, the populations of included studies were mainly from North American, Europe, and Asian countries, and we also performed subgroup analysis according to their different races.

\section{Statistical analysis}

RevMan v5.3 software was used for statistical analyses. The hazard ratio (HR), 95\% CI, standard error (SE), and $\log [\mathrm{HR}]$ for OS and PFS were extracted or calculated from published RCT data according to the methods described by Tierney et al. [57]. The ORR, CRR PRR, and G3/4 toxicity events in eligible RCTs were extracted from published studies. For those RCTs in which survival HR was not revealed in the report, it was estimated from the provided survival-curve using the Engauge Digitizer. The 95\%CI of the survival HR was estimated using the delta method [57]. The small square and its size represents the HR (or OR) and weight of each RCT in the forest, respectively. The horizontal line through the small square represents the $95 \% \mathrm{CI}$. The small diamond at the bottom of the forest plot represents the pooled HR (or OR), and its width represents the 95\%CI. Cochran's Q test and $\mathrm{I}^{2}$ statistics were used to evaluate the heterogeneity of the included RCTs. Statistical heterogeneity was considered when $P$ $<0.10$ or $\mathrm{I}^{2}>50 \%$, with the random-effects model used in this case; otherwise, the fixed-effects model was applied. A funnel plot was used to show potential publication bias when there were enough eligible articles. $P<0.05$ was defined as a significant two-way $P$-value. All measured endpoints were presented in the form of forest maps.

\section{Data availability}

As the secondary user of deidentified patient-level clinical trial data, we are not authorized to share the data based on the data use agreements.

\section{Abbreviations}

RCTs: randomized controlled trials; OS: overall survival; PFS: progression-free survival; G3/4: grade 3 or 4; CI: confidence interval; HR: hazard ratio; OR: 
odds ratio; ORR: overall response rate; CRR: complete response rate; PRR: partial response rate; DDR: dosedensity ratio; AUC: area under the curve; NCCN: National Comprehensive Cancer Network; SE: standard error; MESH: the Medical Subject Heading.

\section{AUTHOR CONTRIBUTIONS}

$\mathrm{CC}$ and SL were responsible for the study conception and design. SL and TP designed the search strategy, screened the abstracts and full texts, extracted the data, and assessed the risk of bias of included RCTs. SL finished the manuscript, and $\mathrm{CC}$ took charge of supervising the manuscript. All authors read and approved the final manuscript.

\section{CONFLICTS OF INTEREST}

All authors have no conflicts of interests to declare.

\section{FUNDING}

This work was supported by National Natural Science Foundation of China $(82072895,81630060)$.

\section{Editorial Note}

${ }^{\&}$ This corresponding author has a verified history of publications using the personal email address for correspondence.

\section{REFERENCES}

1. Sung $H$, Ferlay J, Siegel $R L$, Laversanne $M$, Soerjomataram I, Jemal A, Bray F. Global Cancer Statistics 2020: GLOBOCAN Estimates of Incidence and Mortality Worldwide for 36 Cancers in 185 Countries. CA Cancer J Clin. 2021; 71:209-49. https://doi.org/10.3322/caac.21660 PMID:33538338

2. Giaccone G, Splinter TA, Debruyne C, Kho GS, Lianes $P$, van Zandwijk N, Pennucci MC, Scagliotti G, van Meerbeeck J, van Hoesel Q, Curran D, Sahmoud T, Postmus PE. Randomized study of paclitaxel-cisplatin versus cisplatin-teniposide in patients with advanced non-small-cell lung cancer. The European Organization for Research and Treatment of Cancer Lung Cancer Cooperative Group. J Clin Oncol. 1998; 16:2133-41.

https://doi.org/10.1200/JCO.1998.16.6.2133 PMID: 9626213

3. McGuire WP, Hoskins WJ, Brady MF, Kucera PR, Partridge EE, Look KY, Clarke-Pearson DL, Davidson M. Cyclophosphamide and cisplatin compared with paclitaxel and cisplatin in patients with stage III and stage IV ovarian cancer. N Engl J Med. 1996; 334:1-6. https://doi.org/10.1056/NEJM199601043340101 PMID:7494563

4. Holmes FA, Walters RS, Theriault RL, Forman $A D$, Newton LK, Raber MN, Buzdar AU, Frye DK, Hortobagyi GN. Phase II trial of taxol, an active drug in the treatment of metastatic breast cancer. J Natl Cancer Inst. 1991; 83:1797-805.

https://doi.org/10.1093/jnci/83.24.1797-a

PMID: 1683908

5. Ball HG, Blessing JA, Lentz SS, Mutch DG. A phase II trial of paclitaxel in patients with advanced or recurrent adenocarcinoma of the endometrium: a Gynecologic Oncology Group study. Gynecol Oncol. 1996; 62:278-81.

https://doi.org/10.1006/gyno.1996.0227

PMID:8751561

6. Papadimitriou CA, Sarris K, Moulopoulos LA, Fountzilas G, Anagnostopoulos A, Voulgaris Z, Gika D, Giannakoulis N, Diakomanolis E, Dimopoulos MA. Phase II trial of paclitaxel and cisplatin in metastatic and recurrent carcinoma of the uterine cervix. J Clin Oncol. 1999; 17:761-6.

https://doi.org/10.1200/JCO.1999.17.3.761

PMID:10071264

7. Katsumata N, Yasuda M, Isonishi S, Takahashi F, Michimae H, Kimura E, Aoki D, Jobo T, Kodama S, Terauchi F, Sugiyama T, Ochiai K, and Japanese Gynecologic Oncology Group. Long-term results of dose-dense paclitaxel and carboplatin versus conventional paclitaxel and carboplatin for treatment of advanced epithelial ovarian, fallopian tube, or primary peritoneal cancer (JGOG 3016): a randomised, controlled, open-label trial. Lancet Oncol. 2013; 14:1020-6.

https://doi.org/10.1016/S1470-2045(13)70363-2 PMID:23948349

8. Sakakibara $T$, Inoue $A$, Sugawara $S$, Maemondo $M$, Ishida $T$, Usui $K$, Abe $T$, Kanbe $M$, Watanabe $H$, Saijo $Y$, Nukiwa T. Randomized phase II trial of weekly paclitaxel combined with carboplatin versus standard paclitaxel combined with carboplatin for elderly patients with advanced non-small-cell lung cancer. Ann Oncol. 2010; 21:795-9.

https://doi.org/10.1093/annonc/mdp401 PMID:19815651

9. Belani CP, Ramalingam S, Perry MC, LaRocca RV, Rinaldi D, Gable PS, Tester WJ. Randomized, phase III study of weekly paclitaxel in combination with carboplatin versus standard every-3-weeks administration of carboplatin and paclitaxel for 
patients with previously untreated advanced nonsmall-cell lung cancer. J Clin Oncol. 2008; 26:468-73. https://doi.org/10.1200/JCO.2007.13.1912 PMID:18202422

10. Ettinger DS, Wood DE, Aggarwal C, Aisner DL, Akerley W, Bauman JR, Bharat A, Bruno DS, Chang JY, Chirieac LR, D’Amico TA, Dilling TJ, Dobelbower M, et al, and OCN. NCCN Guidelines Insights: Non-Small Cell Lung Cancer, Version 1.2020. J Natl Compr Canc Netw. 2019; 17:1464-72.

https://doi.org/10.6004/jnccn.2019.0059 PMID:31805526

11. Gradishar WJ, Anderson BO, Abraham J, Aft R, Agnese $D$, Allison $\mathrm{KH}$, Blair SL, Burstein HJ, Dang C, Elias AD, Giordano SH, Goetz MP, Goldstein LJ, et al. Breast Cancer, Version 3.2020, NCCN Clinical Practice Guidelines in Oncology. J Natl Compr Canc Netw. 2020; 18:452-78.

https://doi.org/10.6004/jnccn.2020.0016 PMID:32259783

12. Daly MB, Pilarski R, Yurgelun MB, Berry MP, Buys SS, Dickson P, Domchek SM, Elkhanany A, Friedman S, Garber JE, Goggins M, Hutton ML, Khan S, et al. NCCN Guidelines Insights: Genetic/Familial High-Risk Assessment: Breast, Ovarian, and Pancreatic, Version 1.2020. J Natl Compr Canc Netw. 2020; 18:380-91. https://doi.org/10.6004/jnccn.2020.0017 PMID: $\underline{32259785}$

13. Qi M, Li JF, Xie YT, Lu AP, Lin BY, Ouyang T. Weekly paclitaxel improved pathologic response of primary chemotherapy compared with standard 3 weeks schedule in primary breast cancer. Breast Cancer Res Treat. 2010; 123:197-202. https://doi.org/10.1007/s10549-010-1000-2 PMID:20582466

14. Clamp AR, James EC, McNeish IA, Dean A, Kim JW, O’Donnell DM, Hook J, Coyle C, Blagden S, Brenton JD, Naik R, Perren T, Sundar S, et al. Weekly dosedense chemotherapy in first-line epithelial ovarian, fallopian tube, or primary peritoneal carcinoma treatment (ICON8): primary progression free survival analysis results from a GCIG phase 3 randomised controlled trial. Lancet. 2019; 394:2084-95. https://doi.org/10.1016/S0140-6736(19)32259-7 PMID: $\underline{31791688}$

15. Huang TC, Campbell TC. Comparison of weekly versus every 3 weeks paclitaxel in the treatment of advanced solid tumors: a meta-analysis. Cancer Treat Rev. 2012; 38:613-7. https://doi.org/10.1016/j.ctrv.2011.10.008 PMID:22155063

16. Norton L. Theoretical concepts and the emerging role of taxanes in adjuvant therapy. Oncologist. 2001
(Suppl 3); 6:30-5. https://doi.org/10.1634/theoncologist.6-suppl 3-30 PMID:11346683

17. Hudis CA, Schmitz N. Dose-dense chemotherapy in breast cancer and lymphoma. Semin Oncol. 2004 (Suppl 8); 31:19-26.

https://doi.org/10.1053/i.seminoncol.2004.04.004 PMID:15181605

18. Hudis C, Dang C. The development of dose-dense adjuvant chemotherapy. Breast J. 2015; 21:42-51.

https://doi.org/10.1111/tbj.12364

PMID:25530009

19. Rosenberg P, Andersson H, Boman K, Ridderheim M, Sorbe B, Puistola U, Parö G. Randomized trial of single agent paclitaxel given weekly versus every three weeks and with peroral versus intravenous steroid premedication to patients with ovarian cancer previously treated with platinum. Acta Oncol. 2002; 41:418-24.

https://doi.org/10.1080/028418602320404998

PMID: $\underline{12442916}$

20. Chan JK, Brady MF, Penson RT, Huang H, Birrer MJ, Walker JL, DiSilvestro PA, Rubin SC, Martin LP, Davidson SA, Huh WK, O'Malley DM, Boente MP, et al. Weekly vs. Every-3-Week Paclitaxel and Carboplatin for Ovarian Cancer. N Engl J Med. 2016; 374:738-48.

https://doi.org/10.1056/NEJMoa1505067

PMID:26933849

21. Pignata S, Scambia G, Katsaros D, Gallo C, PujadeLauraine E, De Placido S, Bologna A, Weber B, Raspagliesi F, Panici PB, Cormio G, Sorio R, Cavazzini $M G$, et al, and Multicentre Italian Trials in Ovarian cancer (MITO-7), and Groupe d'Investigateurs Nationaux pour l'Etude des Cancers Ovariens et du sein (GINECO), and Mario Negri Gynecologic Oncology (MaNGO), and European Network of Gynaecological Oncological Trial Groups (ENGOT-OV10), and Gynecologic Cancer InterGroup (GCIG) Investigators. Carboplatin plus paclitaxel once a week versus every 3 weeks in patients with advanced ovarian cancer (MITO-7): a randomised, multicentre, open-label, phase 3 trial. Lancet Oncol. 2014; 15:396405.

https://doi.org/10.1016/S1470-2045(14)70049-X PMID:24582486

22. Green MC, Buzdar AU, Smith T, Ibrahim NK, Valero V, Rosales MF, Cristofanilli M, Booser DJ, Pusztai L, Rivera E, Theriault RL, Carter C, Frye D, et al. Weekly paclitaxel improves pathologic complete remission in operable breast cancer when compared with paclitaxel once every 3 weeks. J Clin Oncol. 2005; 23:5983-92. 
https://doi.org/10.1200/JCO.2005.06.232 PMID:16087943

23. Yu KD, Liu GY, Chen CM, Li JW, Wu J, Lu JS, Shen ZZ, Shao ZM. Weekly paclitaxel/carboplatin/trastuzumab therapy improves pathologic complete remission in aggressive HER2-positive breast cancers, especially in luminal-B subtype, compared with a once-every-3weeks schedule. Oncologist. 2013; 18:511-7. https://doi.org/10.1634/theoncologist.2012-0057 PMID:23635560

24. Sparano JA, Wang M, Martino S, Jones V, Perez EA, Saphner T, Wolff AC, Sledge GW Jr, Wood WC, Davidson NE. Weekly paclitaxel in the adjuvant treatment of breast cancer. N Engl J Med. 2008; 358:1663-71.

https://doi.org/10.1056/NEJMoa0707056 PMID:18420499

25. Seidman $A D$, Berry $D$, Cirrincione $C$, Harris L, Muss $H$, Marcom PK, Gipson G, Burstein H, Lake D, Shapiro CL, Ungaro $\mathrm{P}$, Norton L, Winer E, Hudis C. Randomized phase III trial of weekly compared with every-3-weeks paclitaxel for metastatic breast cancer, with trastuzumab for all HER-2 overexpressors and random assignment to trastuzumab or not in HER-2 nonoverexpressors: final results of Cancer and Leukemia Group B protocol 9840. J Clin Oncol. 2008; 26:1642-9.

https://doi.org/10.1200/JCO.2007.11.6699 PMID: 18375893

26. Perez EA, Suman VJ, Rowland KM, Ingle JN, Salim M, Loprinzi CL, Flynn PJ, Mailliard JA, Kardinal CG, Krook JE, Thrower AR, Visscher DW, Jenkins RB. Two concurrent phase II trials of paclitaxel/carboplatin/ trastuzumab (weekly or every-3-week schedule) as first-line therapy in women with HER2-overexpressing metastatic breast cancer: NCCTG study 983252 . Clin Breast Cancer. 2005; 6:425-32.

https://doi.org/10.3816/CBC.2005.n.047 PMID:16381626

27. Mathur A, Rastogi N, Gurjar D, Sai R, Lakesar A, Malhotra H. Safety and efficacy of weekly versus three-weekly paclitaxel plus platinum neoadjuvant chemotherapy in patients with locally advanced squamous cell head and neck carcinoma: A pilot study. South Asian J Cancer. 2018; 7:254-7.

https://doi.org/10.4103/sajc.sajc 1817 PMID:

28. Pathalingappa H, Kumar L. 270PD An open label randomized phase 2, study of weekly vs 3 weekly paclitaxel and carboplatin in stage IVB or recurrent carcinoma cervix. Ann Oncol. 2015; 26:ix80. https://doi.org/10.1093/annonc/mdv525.04
29. Socinski MA, Saleh MN, Trent DF, Dobbs TW, Zehngebot LM, Levine MA, Bordoni R, Stella PJ. A randomized, phase II trial of two dose schedules of carboplatin/paclitaxel/cetuximab in stage IIIB/IV nonsmall-cell lung cancer (NSCLC). Ann Oncol. 2009; 20:1068-73.

https://doi.org/10.1093/annonc/mdn745

PMID: 19188136

30. Belani CP, Dakhil S, Waterhouse DM, Desch CE, Rooney DK, Clark RH, Monberg MJ, Ye Z, Obasaju CK. Randomized phase II trial of gemcitabine plus weekly versus three-weekly paclitaxel in previously untreated advanced non-small-cell lung cancer. Ann Oncol. 2007; 18:110-5.

https://doi.org/10.1093/annonc/mdl344

PMID:17043094

31. Socinski MA, Ivanova A, Bakri K, Wall J, Baggstrom $M Q$, Hensing TA, Mears A, Tynan M, Beaumont J, Peterman AH, Niell HB. A randomized phase II trial comparing every 3-weeks carboplatin/paclitaxel with every 3-weeks carboplatin and weekly paclitaxel in advanced non-small cell lung cancer. Ann Oncol. 2006; 17:104-9.

https://doi.org/10.1093/annonc/mdj016

PMID: 16249215

32. Schuette W, Blankenburg T, Guschall W, Dittrich I, Schroeder M, Schweisfurth $H$, Chemaissani A, Schumann C, Dickgreber N, Appel T, Ukena D. Multicenter randomized trial for stage IIIB/IV nonsmall-cell lung cancer using every-3-week versus weekly paclitaxel/carboplatin. Clin Lung Cancer. 2006; 7:338-43.

https://doi.org/10.3816/clc.2006.n.016 PMID:16640806

33. Marchetti C, De Felice F, Di Pinto A, D'Oria O, Aleksa N, Musella A, Palaia I, Muzii L, Tombolini V, Benedetti Panici P. Dose-dense weekly chemotherapy in advanced ovarian cancer: An updated meta-analysis of randomized controlled trials. Crit Rev Oncol Hematol. 2018; 125:30-4.

https://doi.org/10.1016/i.critrevonc.2018.02.016 PMID:29650273

34. Sterne JA, Sutton AJ, loannidis JP, Terrin N, Jones DR, Lau J, Carpenter J, Rücker G, Harbord RM, Schmid CH, Tetzlaff J, Deeks JJ, Peters J, et al. Recommendations for examining and interpreting funnel plot asymmetry in meta-analyses of randomised controlled trials. BMJ. 2011; 343:d4002.

https://doi.org/10.1136/bmj.d4002 PMID:21784880

35. Page MJ, Sterne JA, Higgins JP, Egger M. Investigating and dealing with publication bias and other reporting biases in meta-analyses of health research: A review. Res Synth Methods. 2021; 12:248-59. 
https://doi.org/10.1002/jrsm.1468

PMID:33166064

36. Sterne JA, Egger M, Smith GD. Systematic reviews in health care: Investigating and dealing with publication and other biases in meta-analysis. BMJ. 2001; 323:101-5. https://doi.org/10.1136/bmj.323.7304.101 PMID: 11451790

37. Zhu L, Chen L. Progress in research on paclitaxel and tumor immunotherapy. Cell Mol Biol Lett. 2019; 24:40.

https://doi.org/10.1186/s11658-019-0164-y PMID:31223315

38. Alqahtani FY, Aleanizy FS, El Tahir E, Alkahtani HM, AlQuadeib BT. Paclitaxel. Profiles Drug Subst Excip Relat Methodol. 2019; 44:205-38. https://doi.org/10.1016/bs.podrm.2018.11.001 PMID: $\underline{31029218}$

39. Vacca A, Ribatti D, lurlaro M, Merchionne F, Nico B, Ria R, Dammacco F. Docetaxel versus paclitaxel for antiangiogenesis. J Hematother Stem Cell Res. 2002; 11:103-18.

https://doi.org/10.1089/152581602753448577 PMID: 11847007

40. Milross CG, Mason KA, Hunter NR, Chung WK, Peters $\mathrm{L}$, Milas L. Relationship of mitotic arrest and apoptosis to antitumor effect of paclitaxel. J Natl Cancer Inst. 1996; 88:1308-14. https://doi.org/10.1093/jnci/88.18.1308 PMID: 8797771

41. Lau DH, Xue L, Young LJ, Burke PA, Cheung AT. Paclitaxel (Taxol): an inhibitor of angiogenesis in a highly vascularized transgenic breast cancer. Cancer Biother Radiopharm. 1999; 14:31-6.

https://doi.org/10.1089/cbr.1999.14.31

PMID: 10850285

42. Griffon-Etienne G, Boucher Y, Brekken C, Suit HD, Jain RK. Taxane-induced apoptosis decompresses blood vessels and lowers interstitial fluid pressure in solid tumors: clinical implications. Cancer Res. 1999; 59:3776-82.

PMID: 10446995

43. Lopes NM, Adams EG, Pitts TW, Bhuyan BK. Cell kill kinetics and cell cycle effects of taxol on human and hamster ovarian cell lines. Cancer Chemother Pharmacol. 1993; 32:235-42.

https://doi.org/10.1007/BF00685842

PMID: 8098996

44. Browder T, Butterfield CE, Kräling BM, Shi B, Marshall $B, O$ 'Reilly MS, Folkman J. Antiangiogenic scheduling of chemotherapy improves efficacy against experimental drug-resistant cancer. Cancer Res.
2000; 60:1878-86.

PMID: 10766175

45. Gao G, Chu H, Zhao L, Gui T, Xu Q, Shi J. A metaanalysis of paclitaxel-based chemotherapies administered once every week compared with once every 3 weeks first-line treatment of advanced nonsmall-cell lung cancer. Lung Cancer. 2012; 76:380-6. https://doi.org/10.1016/j.lungcan.2011.12.001 PMID:22226626

46. Mauri D, Kamposioras K, Tsali L, Bristianou M, Valachis A, Karathanasi I, Georgiou C, Polyzos NP. Overall survival benefit for weekly vs. three-weekly taxanes regimens in advanced breast cancer: A metaanalysis. Cancer Treat Rev. 2010; 36:69-74.

https://doi.org/10.1016/j.ctrv.2009.10.006 PMID:19945225

47. Lamba JK, Lin YS, Thummel K, Daly A, Watkins PB, Strom S, Zhang J, Schuetz EG. Common allelic variants of cytochrome P4503A4 and their prevalence in different populations. Pharmacogenetics. 2002; 12:121-32.

https://doi.org/10.1097/00008571-200203000-00006 PMID:11875366

48. Dai D, Zeldin DC, Blaisdell JA, Chanas B, Coulter SJ, Ghanayem BI, Goldstein JA. Polymorphisms in human CYP2C8 decrease metabolism of the anticancer drug paclitaxel and arachidonic acid. Pharmacogenetics. 2001; 11:597-607.

https://doi.org/10.1097/00008571-200110000-00006 PMID:11668219

49. Lynch DT, Koya S, Acharya U. Mantle Cell Lymphoma. 2021. In: StatPearls. Treasure Island (FL): StatPearls Publishing. 2022.

PMID: $\underline{30725670}$

50. Konala VM, Madhira BR, Ashraf S, Graziano S. Use of Immunotherapy in Extensive-Stage Small Cell Lung Cancer. Oncology. 2020; 98:749-54. https://doi.org/10.1159/000508516 PMID:32663833

51. Dalton HJ, Yu X, Hu L, Kapp DS, Benjamin I, Monk BJ, Chan JK. An economic analysis of dose dense weekly paclitaxel plus carboplatin versus every-3-week paclitaxel plus carboplatin in the treatment of advanced ovarian cancer. Gynecol Oncol. 2012; 124:199-204.

https://doi.org/10.1016/j.ygyno.2011.09.028 PMID:22055763

52. Benedict A, Cameron DA, Corson H, Jones SE. An economic evaluation of docetaxel and paclitaxel regimens in metastatic breast cancer in the UK. Pharmacoeconomics. 2009; 27:847-59.

https://doi.org/10.2165/10899510-000000000-00000 PMID:19803539 
53. Sharma D, Wojtynek J, Fox KM, Cooper C, Dokubo I. Cost of home vs clinic administration of paclitaxel in metastatic breast cancer. Am J Manag Care. 2021; 27:SP46-50.

https://doi.org/10.37765/ajmc.2021.88563

PMID:33395244

54. Liberati A, Altman DG, Tetzlaff J, Mulrow C, Gøtzsche PC, loannidis JP, Clarke M, Devereaux PJ, Kleijnen J, Moher D. The PRISMA statement for reporting systematic reviews and meta-analyses of studies that evaluate healthcare interventions: explanation and elaboration. BMJ. 2009; 339:b2700.

https://doi.org/10.1136/bmj.b2700

PMID:19622552

55. Marchetti C, De Felice F, Musella A, Palaia I, Monti M, Musio D, Muzii L, Tombolini V, Benedetti Panici P. Weekly versus three weeks chemotherapy for advanced ovarian cancer: a meta-analysis. Oncotarget. 2016; 7:58709-15.

https://doi.org/10.18632/oncotarget.11094

PMID:27509061
56. Higgins JP, Altman DG, Gøtzsche PC, Jüni $P$, Moher D, Oxman AD, Savovic J, Schulz KF, Weeks L, Sterne JA, and Cochrane Bias Methods Group, and Cochrane Statistical Methods Group. The Cochrane Collaboration's tool for assessing risk of bias in randomised trials. BMJ. 2011; 343:d5928.

https://doi.org/10.1136/bmj.d5928

PMID:22008217

57. Tierney JF, Stewart LA, Ghersi D, Burdett S, Sydes MR. Practical methods for incorporating summary timeto-event data into meta-analysis. Trials. 2007; 8:16. https://doi.org/10.1186/1745-6215-8-16

PMID:17555582 


\section{SUPPLEMENTARY MATERIALS}

\section{Supplementary Figures}

\section{OS}

Study or Subgroup log [Hazard Ratio]

Rosenberg 2002

Katsumata 2013

Pignata 2014

Chan 2016

Perez 2005

Seidman 2008

Sparano 2008

Schuette 2006

Socinski 2006

Belani 2007

Belani 2008

Socinski 2009

Sakakibara 2010

0.1484

$-0.2357$

0.174

$-0.0619$

0.6539

$-0.2485$

0.2776

0.0296

$-0.2744$

$-0.2357$

0.0862

0.2231

0.207
SE

$0.196 \quad 3.6 \%$

$0.1155 \quad 10.3 \%$

$0.1313 \quad 8.0 \%$

$0.136 \quad 7.5 \%$

$0.955 \quad 0.2 \%$

$0.093 \quad 15.9 \%$

$0.1315 \quad 8.0 \%$

$0.0745 \quad 24.9 \%$

$0.1839 \quad 4.1 \%$

$0.2542 \quad 2.1 \%$

$0.1092 \quad 11.6 \%$

$0.2277 \quad 2.7 \%$

$0.3333 \quad 1.2 \%$
Hazard Ratio

IV, Fixed, 95\%CI

$1.16[0.79,1.70]$

$0.79[0.63,0.99]$

$1.19[0.92,1.54]$

$0.94[0.72,1.23]$

$0.52[0.08,3.38]$

$0.78[0.65,0.94]$

$1.32[1.02,1.71]$

$1.03[0.89,1.19]$

$0.76[0.53,1.09]$

$0.79[0.48,1.30]$

$1.09[0.88,1.35]$

$1.25[0.80,1.95]$

$1.23[0.64,2.36]$

$100 \% \quad 0.98[0.91,1.06]$

Total (95\% CI)

Heterogeneity: $\mathrm{Chi}^{\wedge} 2=23.73, \mathrm{df}=12(\mathrm{P}=0.02) ; \mathrm{I}^{\wedge} 2=49 \%$ Test for overall effect: $\mathrm{Z}=0.50(\mathrm{P}=0.62)$

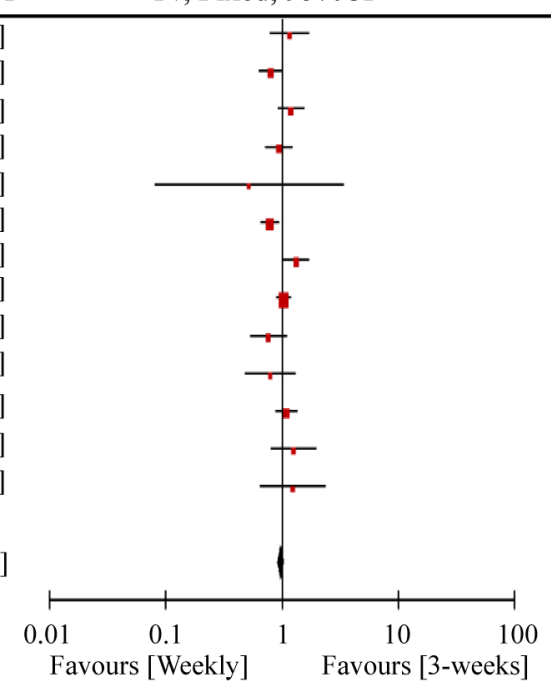

Hazard Ratio IV, Fixed, 95\%CI

Supplementary Figure 1. The forest plot of HR for OS in the weekly paclitaxel compared to 3-weeks paclitaxel regimen. HR: hazard ratio; OS: overall survival.

OS

\begin{tabular}{|c|c|c|c|c|}
\hline Study or Subgroup & $\log$ [Hazard Ratio] & $\mathrm{SE}$ & Weight & IV, Random, 95\% \\
\hline \multicolumn{5}{|c|}{ 1. Overall survival in the weekly dose-dense analysis } \\
\hline Pignata 2014 & 0.174 & 0.1313 & $14.3 \%$ & $1.19[0.92,1.54]$ \\
\hline Schuette 2006 & 0.0296 & 0.0745 & $25.6 \%$ & $1.03[0.89,1.19]$ \\
\hline Subtotal (95\% CI) & & & $39.9 \%$ & $1.07[0.94,1.21]$ \\
\hline \multicolumn{5}{|c|}{$\begin{array}{l}\text { Heterogeneity: } \mathrm{Chi}^{\wedge} 2=0.91, \mathrm{df}=1(\mathrm{P}=0.34) ; \mathrm{I}^{\wedge} 2=0 \% \\
\text { Test for overall effect: } \mathrm{Z}=1.00(\mathrm{P}=0.32)\end{array}$} \\
\hline \multicolumn{5}{|c|}{ 2. Overall survival in the semi-weekly dose-dense analysis } \\
\hline Belani 2008 & 0.0862 & 0.1092 & $17.9 \%$ & $1.09[0.88,1.35]$ \\
\hline Chan 2016 & -0.0619 & 0.136 & $13.6 \%$ & $0.94[0.72,1.23]$ \\
\hline Katsumata 2013 & -0.2357 & 0.1155 & $16.7 \%$ & $0.79[0.63,0.99]$ \\
\hline Sakakibara 2010 & 0.207 & 0.3333 & $3.1 \%$ & $1.23[0.64,2.36]$ \\
\hline Socinski 2006 & -0.2744 & 0.1839 & $8.7 \%$ & $0.76[0.53,1.09]$ \\
\hline Subtotal (95\% CI) & & & $60.1 \%$ & $0.92[0.78,1.08]$ \\
\hline \multicolumn{5}{|c|}{$\begin{array}{l}\text { Heterogeneity: } \mathrm{Chi}^{\wedge} 2=6.10, \mathrm{df}=4(\mathrm{P}=0.20) ; \mathrm{I}^{\wedge} 2=33 \% \\
\text { Test for overall effect: } \mathrm{Z}=1.02(\mathrm{P}=0.31)\end{array}$} \\
\hline Total $(95 \%$ CI) & & & $100 \%$ & $0.98[0.87,1.11]$ \\
\hline $\begin{array}{l}\text { Heterogeneity: } \mathrm{Chi}^{\wedge} 2 \\
\text { Test for overall effect: } \\
\text { Test for subgroup diff }\end{array}$ & $\begin{array}{l}\text { 9.48, } \mathrm{df}=6(\mathrm{P}=0.15) \\
=0.29(\mathrm{P}=0.77) \\
\text { ences: } \mathrm{Chi}^{\wedge} 2=2.02, \mathrm{~d}\end{array}$ & $2=37 \%$ & & \\
\hline
\end{tabular}

Hazard Ratio IV, Random, 95\%CI

Supplementary Figure 2. The forest plot of HR for OS in the subgroup analysis based on carboplatin administration schedules. HR: hazard ratio; OS: overall survival. 
OS

Hazard Ratio

Hazard Ratio

Study or Subgroup log [Hazard Ratio]

SE Weight IV, Random, 95\%CI

IV, Random, 95\%CI

1. Overall survival in the DDR $>1$ group

Katsumata 2013

$$
-0.2357
$$

Chan 2016

$-0.0619$

0.1155

$10.6 \%$

$0.79[0.63,0.99]$

Seidman 2008

$-0.2485$

0.136

$9.1 \%$

$0.94[0.72,1.23]$

Sparano 2008

0.2776

0.093

$12.4 \%$

$0.78[0.65,0.94]$

Tubtotal (95\% CI)

$41.4 \%$

$1.32[1.02,1.71]$

$41.4 \% \quad 0.93[0.73,1.17]$

Heterogeneity: $\mathrm{Chi}^{\wedge} 2=12.21, \mathrm{df}=3(\mathrm{P}=0.007) ; \mathrm{I}^{\wedge} 2=75 \%$

Test for overall effect: $Z=0.65(P=0.51)$

\section{Overall survival in the $D D R<=1$ group}

Rosenberg 2002

Pignata 2014

Perez 2005

Schuette 2006

Socinski 2006

Belani 2007

Belani 2008

Socinski 2009

Sakakibara 2010

0.1484
0.174
-0.6539
0.0296
-0.2744
-0.2357
0.0862
0.2231
0.207

0.196

0.1313

0.955

0.0745

0.1839

0.2542

0.1092

0.2277

0.3333

Subtotal (95\% CI)

$\begin{array}{ll}5.9 \% & 1.16[0.79,1.70] \\ 9.4 \% & 1.19[0.921 .54] \\ 0.4 \% & 0.52[0.08,3.38] \\ 14.0 \% & 1.03[0.89,1.19] \\ 6.4 \% & 0.76[0.53,1.09] \\ 4.1 \% & 0.79[0.48,1.30] \\ 11.0 \% & 1.09[0.88,1.35] \\ 4.8 \% & 1.25[0.80,1.95] \\ 2.6 \% & 1.23[0.64,2.36] \\ 58.6 \% & 1.05[0.95,1.15]\end{array}$

Heterogeneity: $\mathrm{Chi}^{\wedge} 2=7.04, \mathrm{df}=8(\mathrm{P}=0.53) ; \mathrm{I}^{\wedge} 2=0 \%$

Test for overall effect: $\mathrm{Z}=0.98(\mathrm{P}=0.33)$

\section{Total (95\% CI)}

$100.0 \%$

Heterogeneity: $\mathrm{Chi}^{\wedge} 2=23.73, \mathrm{df}=12(\mathrm{P}=0.02) ; \mathrm{I}^{\wedge} 2=49 \%$

Test for overall effect: $Z=0.17(P=0.87)$

Test for subgroup differences: $\mathrm{Chi}^{\wedge} 2=0.95, \mathrm{df}=1(\mathrm{P}=0.33), \quad \mathrm{I}^{\wedge} 2=0 \%$

$0.99[0.88,1.11]$

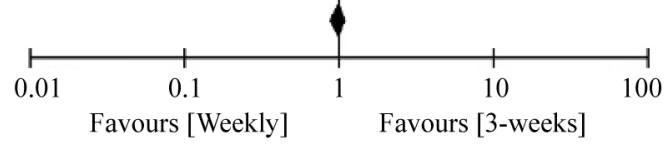

Supplementary Figure 3. The forest plot of HR for OS in the subgroup analysis based on the DDR of paclitaxel. HR: hazard ratio; OS: overall survival; DDR: dose density ratio. 
OS

$\frac{\text { Study or Subgroup } \log \text { [Hazard Ratio] }}{\text { 1. Overall survival in North American }}$

$\begin{array}{lc}\text { Chan 2016 } & -0.0619 \\ \text { Perez 2005 } & 0.6539 \\ \text { Seidman 2008 } & -0.2485 \\ \text { Sparano 2008 } & 0.2776 \\ \text { Socinski 2006 } & -0.2744 \\ \text { Belani 2007 } & -0.2357 \\ \text { Belani 2008 } & 0.0862 \\ \text { Socinski 2009 } & 0.2231 \\ \text { Subtotal (95\% CI) } & \end{array}$

SE Weight IV, Random, 95\%CI

Hazard Ratio

IV, Random, 95\%CI

Heterogeneity: $\mathrm{Tau}^{\wedge} 2=0.03, \mathrm{Chi}^{\wedge} 2=16.18, \mathrm{df}=7(\mathrm{P}=0.02) ; \mathrm{I}^{\wedge} 2=57 \%$

Test for overall effect: $Z=0.40(P=0.69)$

2. Overall survival in Europe

$\begin{array}{lllll}\text { Rosenberg 2002 } & 0.1484 & 0.196 & 5.9 \% & 1.16[0.79,1.70] \\ \text { Pignata 2014 } & 0.174 & 0.1313 & 9.4 \% & 1.19[0.921 .54] \\ \text { Schuette 2006 } & 0.0296 & 0.0745 & 14.0 \% & 1.03[0.89,1.19] \\ \text { Subtotal (95\% CI) } & & & 29.3 \% & 1.08[0.95,1.21]\end{array}$

Heterogeneity: $\mathrm{Tau}^{\wedge} 2=0.00, \mathrm{Chi}^{\wedge} 2=1.08, \mathrm{df}=2(\mathrm{P}=0.58) ; \mathrm{I}^{\wedge} 2=0 \%$

Test for overall effect: $\mathrm{Z}=1.19(\mathrm{P}=0.24)$

\section{Overall survival in Asia}

$\begin{array}{lclll}\text { Katsumata } 2013 & -0.2357 & 0.1155 & 10.6 \% & 0.79[0.63,0.99] \\ \text { Sakakibara 2010 } & 0.207 & 0.3333 & 2.6 \% & 1.23[0.64,2.36] \\ \text { Subtotal (95\% CI) } & & & 13.2 \% & 0.88[0.61,1.29]\end{array}$

Heterogeneity: $\mathrm{Tau}^{\wedge} 2=0.04, \mathrm{Chi}^{\wedge} 2=1.58, \mathrm{df}=1(\mathrm{P}=0.21) ; \mathrm{I}^{\wedge} 2=37 \%$

Test for overall effect: $\mathrm{Z}=0.65(\mathrm{P}=0.52)$

Total $(\mathbf{9 5 \%} \mathrm{CI})$

$100.0 \% \quad 0.99[0.88,1.11]$

Heterogeneity: $\mathrm{Tau}^{\wedge} 2=0.02, \mathrm{Chi}^{\wedge} 2=23.73, \mathrm{df}=12(\mathrm{P}=0.02) ; \mathrm{I}^{\wedge} 2=49 \%$

Test for overall effect: $\mathrm{Z}=0.17(\mathrm{P}=0.87)$

Test for subgroup differences: $\mathrm{Chi}^{\wedge} 2=1.68, \mathrm{df}=2(\mathrm{P}=0.43), \quad \mathrm{I}^{\wedge} 2=0 \%$

$0.94[0.72,1.23]$

$0.52[0.08,3.38]$

$0.78[0.65,0.94]$

$1.32[1.02,1.71]$

$0.76[0.53,1.09]$

$0.79[0.48,1.30]$

$1.09[0.88,1.35]$

$1.25[0.80,1.95]$

$0.97[0.81,1.15]$

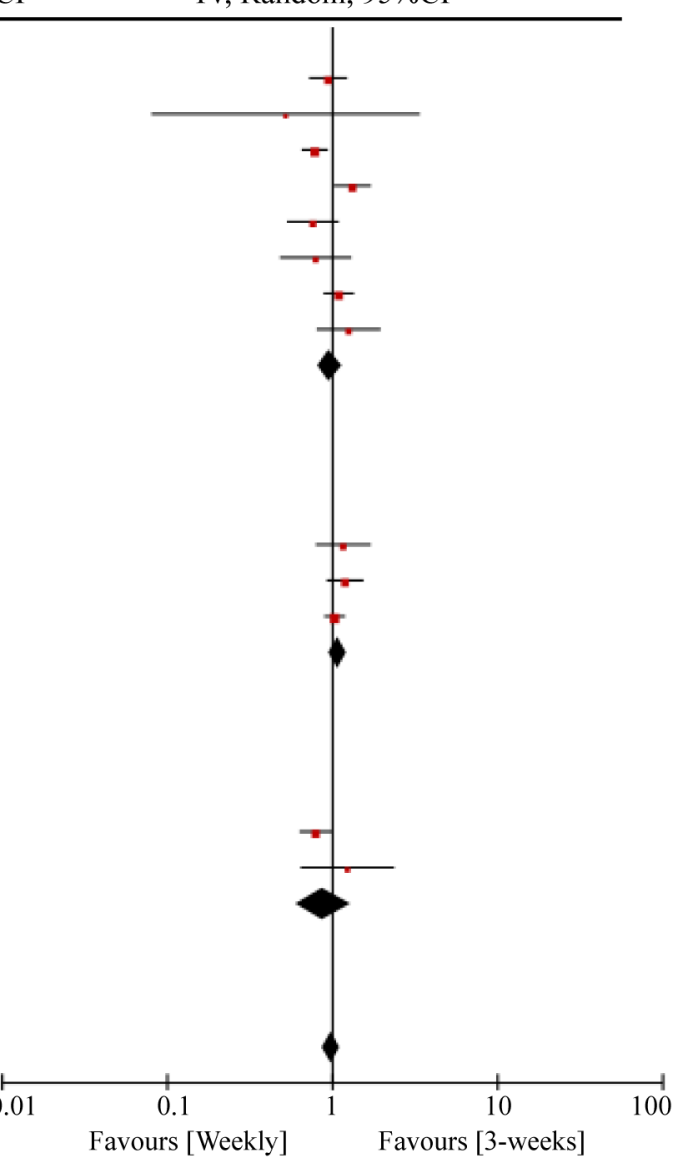

Supplementary Figure 4. The forest plot of HR for OS in the subgroup analysis based on ethnic differences of included populations. HR: hazard ratio; OS: overall survival. 


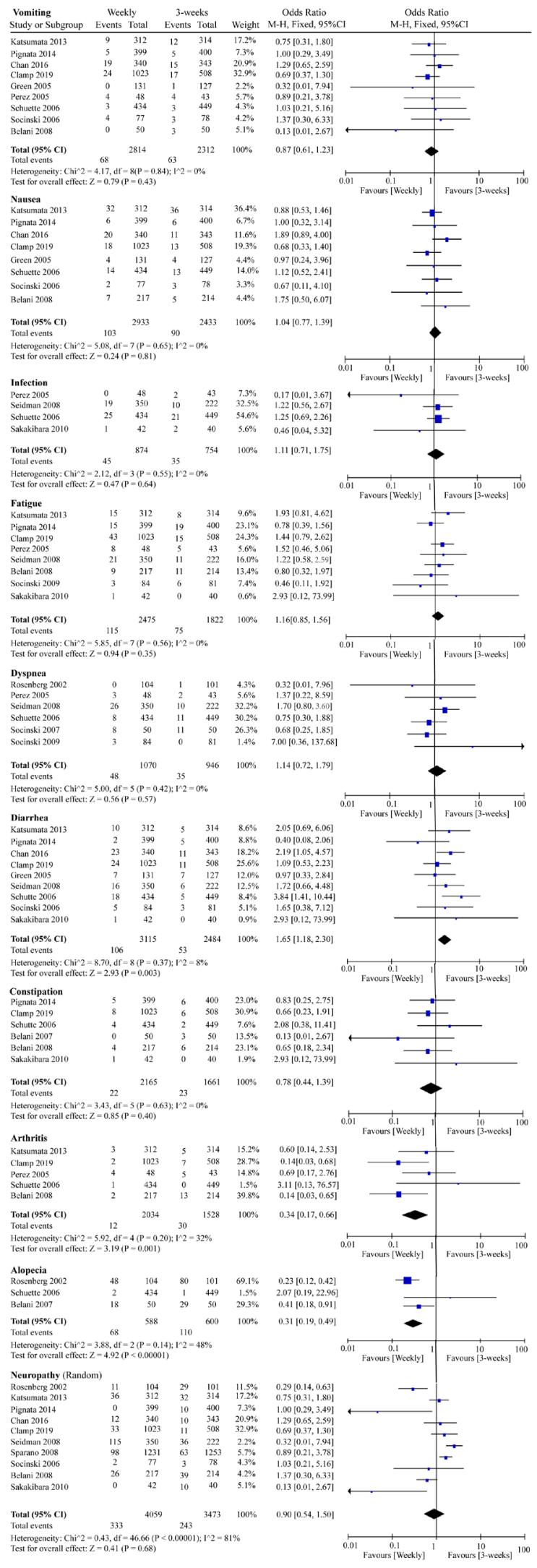

Supplementary Figure 5. The forest plot of OR for non-hematologic toxicities (vomiting, nausea, infection, fatigue, dyspnea, diarrhea, constipation, arthritis, alopecia, and neuropathy) in the weekly paclitaxel compared to 3-weeks paclitaxel regimen. OR: odds ratio. 
A

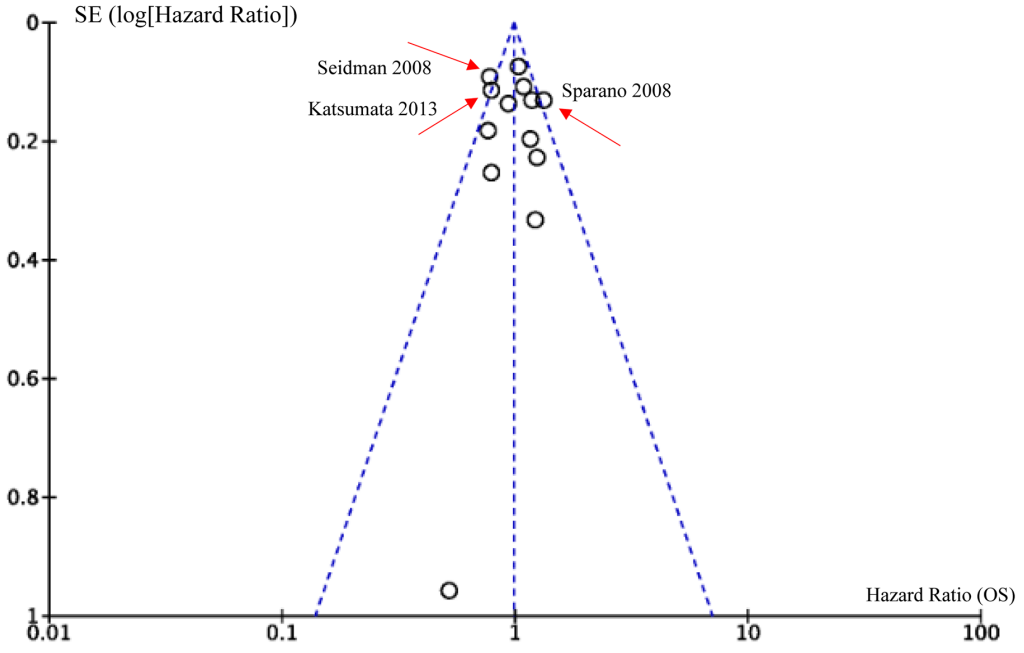

B

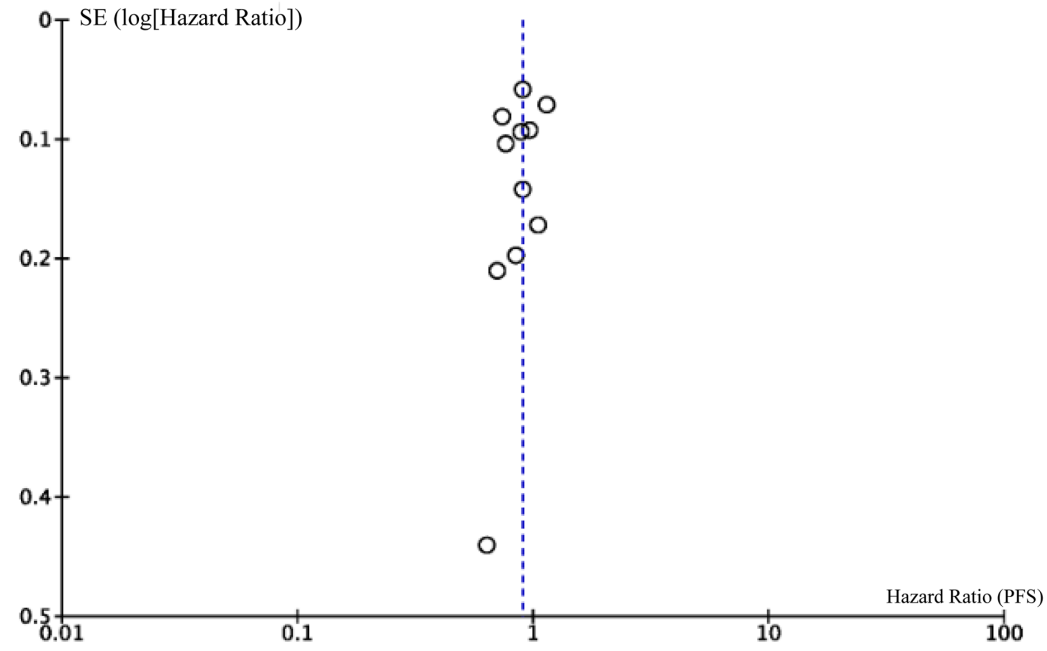

C

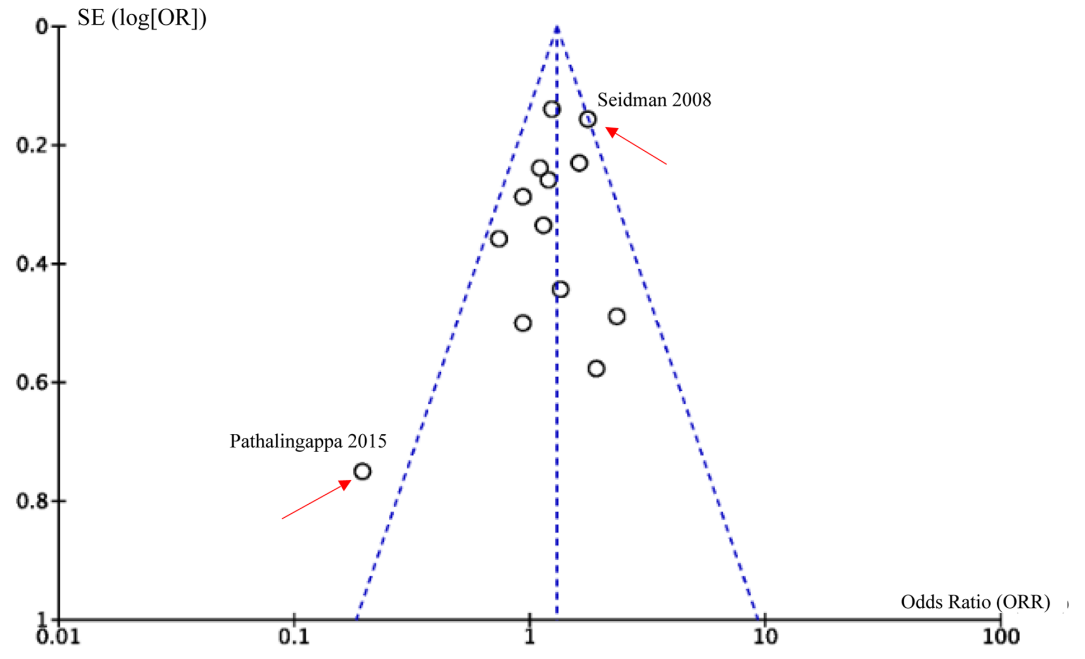

Supplementary Figure 6. The funnel plots for publication bias. (A) for articles measuring the incidence of OS. (B) for articles measuring the incidence of PFS. (C) for articles measuring the incidence of ORR. The vertical blue dotted line and two oblique blue dotted lines represent the position of the combined effect value and its corresponding $95 \%$ confidence interval on the $x$-axis, respectively. The red arrows point to outlier studies. OS: overall survival; PFS: progression-free survival; ORR: overall response rate. 


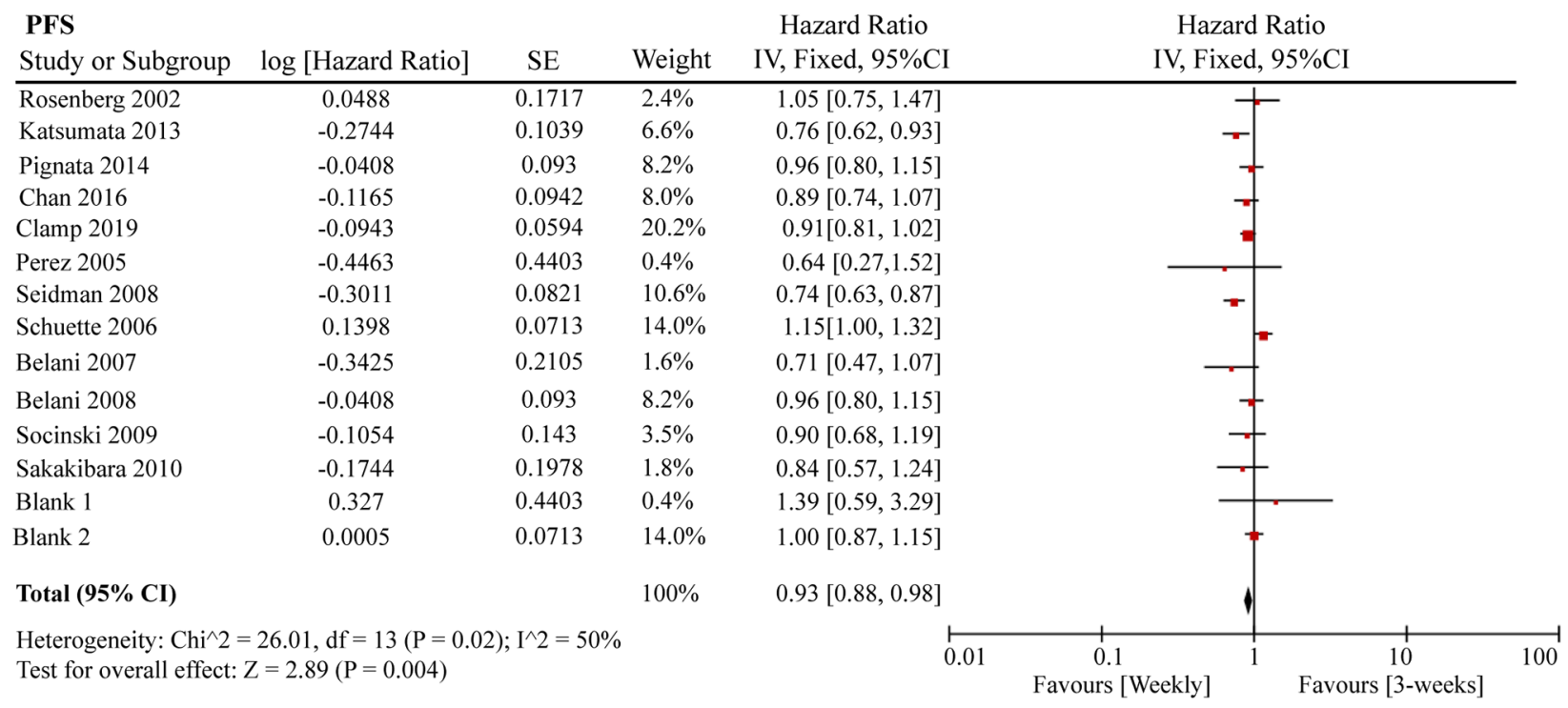

Supplementary Figure 7. The forest plot of adjusted HR by trim and fill for PFS in the weekly paclitaxel compared to 3-weeks paclitaxel regimen. HR: hazard ratio; PFS: progression-free survival.

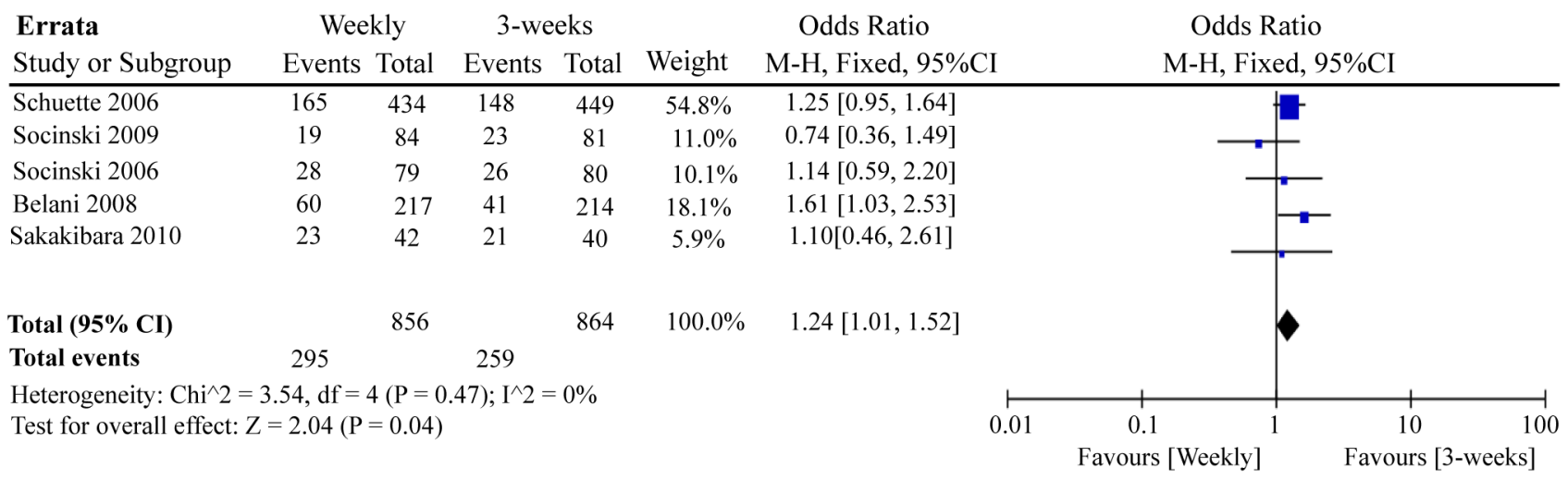

Supplementary Figure 8. The corrected forest plot of OR for response rate in the weekly paclitaxel compared to 3-weeks paclitaxel regimen. 


\section{Supplementary Table}

Supplementary Table 1. The search strategies for related articles in four included databases.

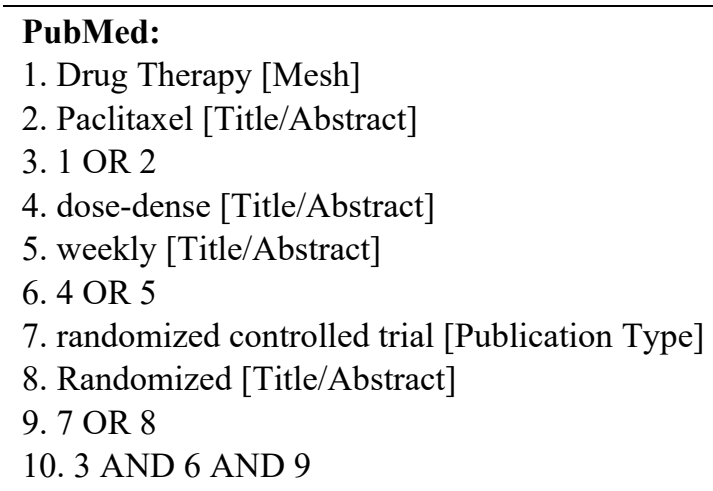

\section{Web of Science:}

1. $\mathrm{TI}=$ paclitaxel

2. $\mathrm{TI}=($ dose-dense OR weekly)

3. $\mathrm{TS}=($ randomized controlled trial OR randomized OR placebo)

4. 1 AND 2 AND 3

Cochrane Library:

1. Neoplasms [Mesh]

2. neoplas* OR cancer* OR carcinom* OR malignan* OR tumor* OR tumour* [Title/Abstract]

3. 1 OR 2

4. weekly [Title/Abstract]

5. dose-dense [Title/Abstract]

6. 4 OR 5

7. Randomized controlled trial [Publication Type]

8. Randomized [Title/Abstract]

9. 7 OR 8

10. Paclitaxel [Title/Abstract]

11. 3 AND 6 AND 9 AND 10

ClinicalTrials.gov:

(Paclitaxel) AND (dose-dense OR weekly) 